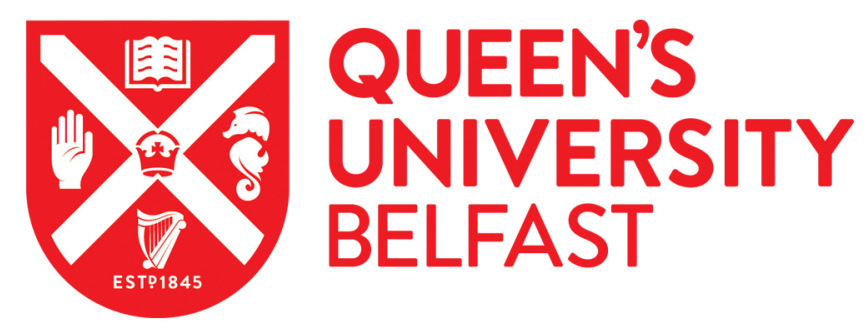

\title{
The Importance of Acetonitrile in the Pharmaceutical Industry and Opportunities for its Recovery from Waste
}

McConvey, I. F., Woods, D., Lewis, M., Gan, Q., \& Nancarrow, P. (2012). The Importance of Acetonitrile in the Pharmaceutical Industry and Opportunities for its Recovery from Waste. Organic Process Research \& Development, 16(4), 612-624. https://doi.org/10.1021/op2003503

Published in:

Organic Process Research \& Development

Document Version:

Peer reviewed version

Queen's University Belfast - Research Portal:

Link to publication record in Queen's University Belfast Research Portal

Publisher rights

Copyright $\odot 2012$ American Chemical Society. This work is made available online in accordance with the publisher's policies. Please refer to any applicable terms of use of the publisher.

\section{General rights}

Copyright for the publications made accessible via the Queen's University Belfast Research Portal is retained by the author(s) and / or other copyright owners and it is a condition of accessing these publications that users recognise and abide by the legal requirements associated with these rights.

Take down policy

The Research Portal is Queen's institutional repository that provides access to Queen's research output. Every effort has been made to ensure that content in the Research Portal does not infringe any person's rights, or applicable UK laws. If you discover content in the Research Portal that you believe breaches copyright or violates any law, please contact openaccess@qub.ac.uk. 


\section{Organic Process \\ Research \& Development}

Subscriber access provided by QUEENS UNIV BELFAST

\section{Full Paper}

\section{The Importance of Acetonitrile in the Pharmaceutical Industry and Opportunities for its Recovery from Waste}

Ian F. Mcconvey, Dean Woods, Moira Lewis, Quan Gan, and Paul Nancarrow

Org. Process Res. Dev., Just Accepted Manuscript • DOI: 10.1021/op2003503 • Publication Date (Web): 27 Feb 2012

Downloaded from http://pubs.acs.org on March 1, 2012

\section{Just Accepted}

"Just Accepted" manuscripts have been peer-reviewed and accepted for publication. They are posted online prior to technical editing, formatting for publication and author proofing. The American Chemical Society provides "Just Accepted" as a free service to the research community to expedite the dissemination of scientific material as soon as possible after acceptance. "Just Accepted" manuscripts appear in full in PDF format accompanied by an HTML abstract. "Just Accepted" manuscripts have been fully peer reviewed, but should not be considered the official version of record. They are accessible to all readers and citable by the Digital Object Identifier (DOI®). "Just Accepted" is an optional service offered to authors. Therefore, the "Just Accepted" Web site may not include all articles that will be published in the journal. After a manuscript is technically edited and formatted, it will be removed from the "Just Accepted" Web site and published as an ASAP article. Note that technical editing may introduce minor changes to the manuscript text and/or graphics which could affect content, and all legal disclaimers and ethical guidelines that apply to the journal pertain. ACS cannot be held responsible for errors or consequences arising from the use of information contained in these "Just Accepted" manuscripts. 


\title{
The Importance of Acetonitrile in the Pharmaceutical Industry and Opportunities for its Recovery from Waste
}

\author{
Ian F McConvey, ${ }^{1}$ Dean Woods, ${ }^{2}$ Moira Lewis, ${ }^{2,3}$ Quan Gan $^{2}$ and Paul Nancarrow*,2,3 \\ ${ }^{1}$ AZ Global Engineering Technology, Alderley Park, Macclesfield, Cheshire, SK10 4TG, \\ England, UK \\ ${ }^{2}$ School of Chemistry and Chemical Engineering, Queen's University Belfast, BT9 5AG, N. \\ Ireland, UK \\ ${ }^{3}$ The QUILL Research Centre, Queen's University Belfast, BT9 5AG, N. Ireland, UK \\ * Corresponding author. Email: p.nancarrow@qub.ac.uk, Tel: +44 28 90974378, Fax: +44 28 \\ 90976524
}




\begin{abstract}
Acetonitrile is regarded as a key solvent in the pharmaceutical industry. However, the volatility in acetonitrile supply in recent years, coupled with its relatively poor environmental profile, has presented significant challenges to its use in manufacturing processes and laboratories. This study investigates the importance of acetonitrile in the pharmaceutical industry and critically examines several options for reducing the exposure of the industry to future supply problems whilst also improving its life cycle management. The physicochemical properties of acetonitrile were compared with other typical process solvents and the Conductor-like Screening Model (COSMO) surfaces and sigma profiles were used to help explain the favourable solvation behaviour of acetonitrile. Several options for the replacement or recovery and recycle of acetonitrile were critically examined in the contexts of environmental, technical and economic feasibility. Azeotropic distillation was found to be the most likely approach to recovering acetonitrile from aqueous waste streams. Several potential breaking agents were assessed against a range of selection rules based on residue curve maps, determined using the Universal Functional Activity Coefficient (UNIFAC) method, and potential processing issues. A range of ionic liquids were screened via the predictive Conductor-like Screening Model for Realistic Solvation (COSMO-RS) approach and several promising candidates were identified. Experimental vapour-liquid equilibria studies were carried out, confirming the feasibility of ionic liquid-enhanced azeotropic distillation as a novel approach to acetonitrile recovery.
\end{abstract}




\section{Introduction}

Acetonitrile $(\mathrm{MeCN})$ is a core solvent in the chemical industries, particularly the pharmaceutical industry, where the global demand accounts for over $70 \%$ of the total market. ${ }^{1}$ The high popularity of $\mathrm{MeCN}$ is due to its excellent solvation ability with respect to a wide range of polar and non-polar solutes, and favourable properties such as low freezing/boiling points, low viscosity and relatively low toxicity. Several key properties of $\mathrm{MeCN}$ are shown in Table 1 and compared with similar solvents. ${ }^{2-5}$ Currently the pharmaceutical and fine chemical industry has two major uses of $\mathrm{MeCN}$ : (a) laboratory use, particularly as a mobile phase in liquid chromatography analytical techniques, ${ }^{6}$ and (b) as an industrial process solvent, for example, in the manufacturing of antibiotics. ${ }^{7}$ Due to the need for very high purity solvents in analytical techniques such as high performance liquid chromatography (HPLC), laboratories tend to use "Analar" grade $\mathrm{MeCN}$, whilst industrial applications favour "technical grade" $\mathrm{MeCN}$ due its lower cost. In both cases, the solvent is very highly refined in terms of purity, typically $>99.9 \%$ for Analar and $>99.5 \%$ for technical grade.

The vast majority of $\mathrm{MeCN}$ is manufactured as a by-product of acrylonitrile production. During the period 2008 to 2009, issues associated with the MeCN supply position were raised as a major concern within the pharmaceutical industry. With a limited demand for acrylonitrile as a result of the world economic downturn, ${ }^{8}$ the supply of MeCN was reduced significantly, probably by at least $50 \%$ in 2008 , although figures are difficult to determine accurately. There was a further shortfall in 2009 and once again it was difficult to predict where the supply would bottom out. During the shortfall period, supply costs were typically increased, peaking at six times the normal cost. Such volatility in price caused interruptions in the normal supply chain as a number of operators reviewed their positioning in the market. This had a major impact on the pharmaceutical industry, with drastic measures, such as stringent stock control, prioritisation of use and sourcing solvent for intermediate suppliers, for example, being taken to mitigate their supply problems in the short term. All new sources of $\mathrm{MeCN}$ on the market had to undergo user requirement trials to ensure no detrimental impact on the process or product.

In addition to supply volatility, $\mathrm{MeCN}$ presents further challenges to its industrial use. A general solvent selection review ${ }^{9}$ recently concluded that there are major issues associated with $\mathrm{MeCN}$ use in the pharmaceutical industry such as difficulties in dealing with waste 
$\mathrm{MeCN}$ and its poor scoring with regard to life cycle management. Therefore, the recent volatility in supply of $\mathrm{MeCN}$ combined with environmental challenges presents the industry with a major incentive to develop new, more sustainable approaches to $\mathrm{MeCN}$ use. Herein is presented a review of the options for $\mathrm{MeCN}$ conservation in use, including a technical assessment based on experimental and predictive analysis.

\section{Why is MeCN such a good solvent?}

As alluded to previously, $\mathrm{MeCN}$ is regarded as a good solvent because of its ability to dissolve a wide variety of fine chemical and pharmaceutical ingredients, with an acceptable environmental profile, even though a sustainable supply cannot be guaranteed. It has, therefore, tended to be a favoured solvent by process chemists, although, for some manufacturing processes, its relatively high cost would be regarded as contributing unduly to the cost of production. $\mathrm{MeCN}$ is also relatively inert, due to the strong $\mathrm{C}-\mathrm{C}$ bond which can only be hydrolysed under extreme conditions, making it an excellent reaction solvent.

The Conductor-like Screening Model (COSMO) $\sigma$-profile ${ }^{10}$ is a useful qualitative tool in explaining the solvent properties of molecules, as shown in Figure 1 for four different solvents: MeCN, water, NMP and hexane. The $\sigma$-profile is a statistical representation of the surface charge distribution on a given molecule as determined from the quantum-based COSMO calculation ${ }^{11}$ and it is possible to use the profiles to interpret the likelihood of a molecule to form strong Coulomb interactions with a wide variety of compounds. This is illustrated via comparison with a strong dielectric, such as water, and a non-polar molecule such as hexane. The abscissa of the profile describes the electron density of the molecular surface with positive values indicating a high electron density and electronegativity whilst negative values indicate low electron density, or electropositive regions. The ordinate describes the relative areas of molecular surface possessing such electron densities. Water is represented by the uppermost surface plot followed by $\mathrm{MeCN}$ in the centre and finally hexane as the lowermost plot. Notice the narrow profile of hexane, which is centred on the $0.00 \sigma$ value, illustrating the non-polar nature of the compound. The $\sigma$-profile of hexane ranges from -0.5 to $+0.6 \mathrm{e} / \mathrm{A}^{2}$, with a maximum at $-0.1 \mathrm{e} / \mathrm{A}^{2}$ arising from the hydrogens, and a shoulder at about $+0.2 \mathrm{e} / \mathrm{A}^{2}$ arising from the exposed surfaces of carbon atoms. The $\sigma$-profiles of other alkanes look very similar, and mainly differ in height due to the differences in the total surface area. Thus the moderate electron density of the functional groups can be recognised in the sigma surface plot via green colour coding. Similarly, if one considers the profile for 
water, the two hydrogen atoms can be identified by the peak at around $-0.015 \mathrm{e} / \mathrm{A}^{2}$, whilst the electronegative oxygen is highlighted at around $+0.015 \mathrm{e} / \mathrm{A}^{2}$. In the colour coding of the surfaces these regions can be recognized as deep blue and deep red respectively. The symmetry of the water profile is very important as this implies partner contact surfaces for each area on adjacent water molecules. Symmetry indicates high molecular affinity within a pure compound and hence water "likes itself" very much, resulting in a high boiling point. Qualitatively, the $\sigma$-profile for $\mathrm{MeCN}$ lies amidst the two extremes mentioned. The electronegative nitrogen atom is illustrated by the peak around $+0.01 \mathrm{e} / \mathrm{A}^{2}$ whilst the electropositive hydrogen atoms are shown via the peaks located around $0.0075 \mathrm{e} / \mathrm{A}^{2}$. Furthermore, the peak at approximately $0.0025 \mathrm{e} / \mathrm{A}^{2}$ highlights the central non-polar carbon atom of the molecule. Once again, these regions can be identified on the sigma surface plot as deep red, light blue and green respectively. Neglecting the obvious steric differences, both water and $\mathrm{MeCN}$ possess similar charge silhouettes. The possession of such a charge distribution results in balance of both moderate and more pronounced polarities highlighting the versatility of the compound to dissolve a range of polar and non-polar media. From Table 1 , the solvent with the physicochemical properties most similar to $\mathrm{MeCN}$, such as dielectric, $\log P$ and miscibility, is $N$-methyl-2-pyrrolidone (NMP). The downside of NMP is that it has a relatively high boiling point and is difficult to recover from aqueous waste, requiring abatement largely by incineration. NMP is also a solvent whose hazard rating is under close review and tending to require more precautions to be taken as more is understood about its systemic mode of action. ${ }^{9}$ 


\section{Review of the options for dealing with the MeCN supply problem}

Given the challenges faced by the pharmaceutical industry as a result of MeCN supply problems in recent years, several options exist for minimising the impact of the volatile market supply. These have been drawn up within the context of the hierarchy of waste minimisation as given in EU Directive 2008/98/EC, ${ }^{12}$ and are summarised in Table 2. A number of hybrid options associated with the main options are also shown in the table. $\mathrm{MeCN}$ sent for recycle is a complex mixture of solvents and other agents. Technically, the best short term solution to the supply shortage of $\mathrm{MeCN}$ is to control and reduce usage and to examine if $\mathrm{MeCN}$ can be recycled for use in other manufacturing sectors to free up use of 'virgin' MeCN for the pharmaceutical industry.

Recycle and reuse is by far the most popular activity for managing MeCN supply and demand. The method that has reached commercial potential is azeotropic distillation although a number of other more novel techniques such as membrane filtration and pervaporation have had some limited success.

A multi-stage column will have the capability to recover MeCN using a breaking agent. However, following the guidelines ${ }^{13}$ issued by the International Conference on Harmonisation of Technical Requirements for Registration of Pharmaceuticals for Human Use (ICH), solvents classified as ICH Class 3 (low toxicity potential) or, perhaps, Class 2 (solvents to be limited) would be preferred. A number of current good manufacturing practice (cGMP) hurdles need to be overcome to reuse MeCN. From a sustainability point of view, the most powerful corporate social responsibility approach would be to review previous activity in MeCN supply and reuse. The waste hierarchy can be applied in order of preference: prevent, minimise, reuse, recycle, energy recovery and disposal to the $\mathrm{MeCN}-$ supply and use. Prevention is almost impossible due to the physical property characteristics of $\mathrm{MeCN}$ for analytical and process use.

In terms of minimising $\mathrm{MeCN}$ consumption within analytical science, focus has been centred on the development of novel HPLC methods which avoid MeCN use entirely. Alcohols such as methanol ${ }^{14-16}$ and ethanol ${ }^{17}$ have been proposed for a number of limited systems. In this manner the pharmaceutical industry can also moderate its laboratory use of $\mathrm{MeCN}$. However, the versatility of $\mathrm{MeCN}$ is impossible to reproduce with other such solvents over a wide range of systems. 


\section{Relevant previous research on $\mathrm{MeCN}$ replacement or recovery}

In the past two decades, significant efforts have been taken to investigate and develop technologies for dealing with the sustainability issues associated with $\mathrm{MeCN}$ use in the pharmaceutical industry. The research and technological developments can be subcategorised into four main areas: solvent substitution; recycle using azeotropic distillation; recycle using physical separations; novel manufacturing processes. For convenience, these have been summarized in Table 3, with further explanation given under the sub-headings below. A further section on more recent developments using predictive approaches to identifying possible approaches to $\mathrm{MeCN}$ recovery is also included.

\subsection{Solvent substitution}

The impact of the MeCN shortage led several researchers to investigate the replacement of $\mathrm{MeCN}$ in pharmaceutical HPLC applications with readily available and low cost alternatives such as methanol or ethanol. Whilst some success has been reported as described earlier, the studies are limited to a few isolated HPLC applications and the authors concede that, when available, $\mathrm{MeCN}$ remains the preferred mobile phase in such cases. Furthermore, due to their relatively high reactivities, methanol and ethanol would be inappropriate to replace $\mathrm{MeCN}$ in most applications as a reaction solvent.

There is a general movement within the SHE community to remove solvents that have specific issues; for example, in recent times, industrial use of dichloromethane has been significantly restricted in Europe due to safety concerns. ${ }^{18}$ Within industry, therefore, the view should be to largely remove $\mathrm{MeCN}$ from process development as early as possible to avoid any legacy issues that may occur with supply or other issues at later stages. From the point of view of the process chemist, however, this approach is seldom adopted because $\mathrm{MeCN}$ is such a useful reaction solvent for the reasons outlined earlier.

\subsection{Azeotropic distillation for $\mathrm{MeCN}$ recovery}

Several researchers have investigated the use of extractive and azeotropic distillation to achieve the recovery of $\mathrm{MeCN}$ from aqueous waste. Acosta-Esquijarosa et al. ${ }^{19}$ proposed a combined process of butyl-acetate solvent extraction followed by distillation. Using this technique the authors claimed an $83.4 \%$ recovery of $\mathrm{MeCN}$ with a purity of $98.51 \%$. Gomez et al. $^{20}$ proposed novel methods using hybrid pervaporation-distillation units for $\mathrm{MeCN}$ recovery. This work did not cover the impact of the potential decomposition of butyl acetate 
to form butanol and acetic acid. From Table 4a, it is possible to identify a number of azeotropes that will influence the quality of the separation of $\mathrm{MeCN}$ for butyl acetate e.g. $\mathrm{BuOH} / \mathrm{BuOAc}, \mathrm{BuOH} / \mathrm{HOAc}$ and various other azeotropes if small amounts of water are formed. The azeotrope may also be broken via the use of an entrainer, i.e. an additive which shifts the thermodynamic equilibrium in such a way that the azeotrope is eliminated. Details on the processes and feasibility of such operations have been offered by Bernot et al. ${ }^{21}$ and Dussel and Sticklmair, ${ }^{22}$ whilst a complete overview of entrainer selection techniques for homogeneous azeotropic batch distillation has been given by Rodriguez-Donis et al. ${ }^{23}$ The same group also investigated heterogeneous azeotropic distillation by using an acrylonitrile entrainer within aqueous $\mathrm{MeCN}$ batches yielding a recovery close to $80 \% .{ }^{24}$ However, due to the use of acrylonitrile, the co-product of $\mathrm{MeCN}$, this technique has little potential impact on $\mathrm{MeCN}$ shortage. To address this problem, the same researchers screened several alternative entrainers by simulating, via the Universal Functional Activity Coefficient (UNIFAC) method, the separation of $\mathrm{MeCN}$-water systems using heterogeneous batch distillation, ${ }^{25}$ identifying two potential entrainers, hexylamine and butyl acetate, from various amines, alcohols, esters, ketones and aromatics.

"Salting out" involves the preferential solvation of salt ions in water at the expense of the tertiary component thus forcing the formation of biphasic systems. Ligette et al. ${ }^{26}$ illustrated that $\mathrm{MeCN}$-water phase separation can be induced at $25{ }^{\circ} \mathrm{C}$ with addition of $\mathrm{NaCl}$. Building upon this, Gu and $\mathrm{Shih}^{27}$ obtained a $60 \%$ recovery of MeCN from an aqueous HPLC effluent stream using a combination of phosphate salts and cooling to $4{ }^{\circ} \mathrm{C}$. Zhang et $\mathrm{al}^{28}$ examined the extraction of platinum group metals (PGM) from aqueous solutions using $\mathrm{NaCl}-\mathrm{MeCN}$ diisopentyl sulphide to form a three-liquid-phase-system. The authors present the aforementioned as an optimum system for PGM recovery furthermore highlighting the adept ability of salts to induce phase separation in aqueous MeCN systems. However, one inconvenience when using this technique is the need to use a $\mathrm{pH}$ buffering agent to protect sensitive components such as enzymes, for example. The use of salts may also be problematic in that they, under certain conditions, may precipitate out of solution, leading to fouling problems in process equipment. Furthermore, the prospect of unwanted reactions with impurities and complications due to corrosion may negate the use of such additives. Such problems may be overcome via the use of dissimilar mass separating agents such as sugars. "Sugaring out" is another innovative technique which operates in a similar fashion to salting out however the additive here is usually a monomeric sugar or disaccharide. In such systems 
the sugars preferentially hydrogen bond to the water molecules forcing the $\mathrm{MeCN}$ into a distinct phase. The concept was proven by Wang et $\mathrm{al}^{29}$ with glucose, fructose, xylose, arabinose, sucrose, and maltose; however, it was unsuccessful when using polysaccharides. When considering the partition of syringic acid and furfural the concentration of said components in the organic phase increased with sugar concentration. Glucose was the most effective of the sugars studied. Dhamole et al. ${ }^{30}$ investigated the effect of glucose concentration, temperature and initial amount of $\mathrm{MeCN}$ on the sugaring out process to recover proteins from aqueous solutions. As a result, an $83 \%(\mathrm{v} / \mathrm{v}) \mathrm{MeCN}$ enrichment of the organic phase was achieved at $6^{\circ} \mathrm{C}$ and 0.012 mole fraction glucose. Sugars, however, carry the risk of microbial growth, which could present significant issues in pharmaceutical processing. Furthermore, like salts, sugars may precipitate from solution during processing and lead to fouling issues.

Traditional laboratory methods of subzero cooling (to approx. $-20{ }^{\circ} \mathrm{C}$ ) to crystallise out water for removal by filtration are associated with high operating costs. Hence, such techniques have arisen as a direct result of MeCN supply and demand in an aid to keep costs down by recycling the solvent internally in a cost effective manner. That being said, the industrial applications of such techniques are highly attractive.

Ionic liquids have attracted significant attention recently as potential azeotrope breakers for a wide range of systems. They are essentially salts which are liquid at or near room temperature and are typically made up of organic cations and inorganic anions, thereby combining some of the properties of organic entrainers with those of inorganic salts. The advantages of ionic liquids include their negligible vapour pressures, ${ }^{31}$ making their separation and recycle of relatively straightforward, and the fact that their physical and thermodynamic properties can be tuned by varying the cation-anion combination and hydrocarbon chain lengths. It has been estimated that, theoretically, there are over $10^{6}$ possible ionic liquids, each with different physicochemical properties. ${ }^{32}$ Therefore, with the emergence of appropriate computational screening technologies, the potential exists to optimally design ionic liquids as azeotrope breakers for a given separations problem. Whilst the lack of extensive toxicity data for novel ionic liquids is a major barrier to their direct use in pharmaceutical processing in the short to medium term, they have potential to be used as azeotrope breakers where the $\mathrm{MeCN}$ is to be recycled externally to non-cGMP processes. A detailed review of the application of ionic liquids as azeotrope breakers has been recently published by Pereiro et al. ${ }^{33}$ Here the authors cite references for the use of ionic liquids as 
azeotrope breakers in a range of water + alcohol, water + THF, alcohol + ester, alcohol + ketone, alcohol + hydrocarbon, alcohol + halogen and aromatic + aliphatic systems, whilst also offering a comparison with published data regarding more conventional entrainers. Contrast is also made between azeotropic breaking and extractive distillation where appropriate. However, there is no published work on the use of ionic liquids for azeotropic distillation of water + nitrile systems, which is a clearly an area needing urgent attention.

\subsection{Physical separation techniques for $\mathrm{MeCN}$ recycle}

As well as azeotropic distillation, other approaches have been reported for the separation of $\mathrm{MeCN}$ from water. For example, Pfenning and Woermann ${ }^{34}$ describe hyperfiltration experiments using phenolsulfonic acid (PSA) membranes for the separation of MeCN from water. More recent work on the use of commercial membrane based techniques for solvent dehydration has been reviewed by Hoof et al. ${ }^{35}$ Whilst some promising results have been achieved, the major technological challenge in this area is producing membranes of sufficient robustness and chemical stability for commercial use.

Khayet $^{36}$ used the pervaporation process to successfully separate binary solutions of acetone-water, MeCN-water and ethanol-water as well as multicomponent systems using Sulzer Pervap ${ }^{\circledR} 4060$ membranes. More recently, Mandal ${ }^{37}$ examined the separation of MeCN-water systems using Pervap ${ }^{\circledR} 2202$ and nanocomposite PVA-iron oxide membranes delivering up to $99 \%(\mathrm{wt})$ water in the permeate. Both papers suggest that this is an efficient and cost effective separation technique. However, these methods have yet to achieve commercial viability.

\subsection{Novel manufacturing processes}

In addition to elimination of $\mathrm{MeCN}$ use or separation and recycle, many industrial and academic researchers have tried to bypass the $\mathrm{MeCN}$ supply chain problem by introducing a direct manufacturing process for $\mathrm{MeCN}$. There are a number of commercial routes to synthesize $\mathrm{MeCN}$ and recently, Bayer $^{38}$ has developed a process for the manufacture of isocratic grade $\mathrm{MeCN}$ in a pilot plant with a capacity of around $4 \mathrm{~m}^{3}$ per week. NITRALZ ${ }^{\circledR 39}$ is another process for the direct synthesis where after an ammoxidation reaction, pressure swing distillation is utilized to manufacture up to $99.9 \%$ HPLC grade MeCN. Moreover several academic papers have been published highlighting novel manufacturing techniques. Zhang et al. ${ }^{40}$ examined the amination of ethanol to $\mathrm{MeCN}$ over a Ni-doped $\mathrm{Co} / \gamma-\mathrm{Al}_{2} \mathrm{O}_{3}$ 
catalyst with $\mathrm{MeCN}$ being obtained with a yield $>82 \%$ under the optimum reaction conditions (drying at $120^{\circ} \mathrm{C}$ and calcining at $550^{\circ} \mathrm{C}$ ) for $720 \mathrm{~h}$. Furthermore in $2011^{28}$ the authors published the intrinsic kinetics of the process in a fixed bed reactor for the temperature range 613-643 K. A concise overview of previous developments in $\mathrm{MeCN}$ process development was also covered by the authors and shall not be reiterated here. However, one important area considers the use of ethane as a feedstock. Li and Armor ${ }^{41-45}$ have published a number of papers describing the ammoxidation of ethane to $\mathrm{MeCN}$ (Equation 1) over a range of zeolite catalysts indicating that Co-ZSM-5, Co-beta and Co-Nu-87 to be superior with ethane conversions of $38.2 \%, 35.3 \%$ and $26.7 \%$ respectively.

$\mathrm{C}_{2} \mathrm{H}_{6}+\mathrm{NH}_{3}+1.5 \mathrm{O}_{2} \rightarrow \mathrm{C}_{2} \mathrm{H}_{3} \mathrm{~N}+3 \mathrm{H}_{2} \mathrm{O}$

In contrast, Rojas et al. ${ }^{46}$ describe the ammoxidation of ethane over a niobium modified $\mathrm{NiO}$ catalyst with a $19 \% \mathrm{MeCN}$ yield. With further catalyst development and improvements in reaction yield, coupled with the increasing volatility in acetonitrile supply via the existing route, this novel approach has the potential to gain industrial importance.

\subsection{Predictive engineering science approach}

The use of predictive tools in pharmaceutical process development is becoming increasingly important, particularly in the preliminary screening of solvent systems, to reduce costly and time-consuming experimental screening studies. Well established group contribution approaches such as UNIFAC ${ }^{47}$ have been found to work reasonably well when dealing with species containing the more common functional groups. However, where more "exotic" species are involved, as is often the case in pharmaceutical processes or in systems involving ionic liquids, UNIFAC cannot be applied due to the lack of group interaction parameters for many functional groups. Quantum-based a priori approaches to thermodynamic prediction, such as COSMO-RS, ${ }^{10}$ have received significant attention in recent years, due to their wide ranging applicability without the need for experimental data or group interaction parameters. Some work has been carried out recently to investigate the use of COSMO-RS for predicting the solubilities of pharmaceutical compounds ${ }^{48}$ and ionic liquid-based systems. ${ }^{49}$ However, despite the recent interest in COSMO-based approach for predicting phase equilibria, there has been very little attention in the literature given to its use in MeCN-containing systems. 


\section{Case study on the recovery of $\mathrm{MeCN}$ from the $\mathrm{MeCN}$-water-toluene system}

$\mathrm{MeCN}$-water-toluene is a ternary system that is typically encountered in the pharmaceutical industry and can be found in several registered processes. Initially a reaction takes place with $\mathrm{MeCN}$ as the reaction solvent. Separation of the organic and inorganic species is achieved by the addition of water to extract the inorganics. Since acetonitrile is fully miscible with water, it is then necessary to back extract the acetonitrile, and any other organics, into toluene. The ternary liquid-liquid equilibria of the $\mathrm{MeCN}$-water-toluene system at $20{ }^{\circ} \mathrm{C}$ is shown in Figure 2, illustrating typical Type I phase behaviour. The figure also shows good agreement between data obtained in this experimental study, COSMO-RS prediction and previously reported data ${ }^{50}$ for the ternary system.

\subsection{Distillation of the MeCN-water-toluene system}

Due to the formation of several azeotropes, this is a complex system from a separations perspective. The MeCN/water/toluene system has four azeotropes (see Table 4a and 4b) as follows:

(i) $\mathrm{MeCN}$ and water (homogeneous)

(ii) water and toluene (heterogeneous)

(iii) $\mathrm{MeCN}$ and toluene (homogeneous)

(iv) $\mathrm{MeCN} /$ water/toluene (heterogeneous)

$\mathrm{MeCN}$ and water form a homogeneous azeotrope when distilled. Therefore, in principle, if a breaking agent is introduced, it would be possible to continue distilling and condensing until a relatively pure $\mathrm{MeCN}$ stream is achieved. However, this separation will also be influenced by the presence of other impurities in the feed stream. Reduction of water to extremely low levels will probably require an extra dehydration step which would be a slow and time consuming distillation. The ternary azeotrope has the lowest boiling point at atmospheric pressure and, therefore, will come off first in a binary distillation. A number of other solvents that might be present in waste $\mathrm{MeCN}$ are shown in Tables $4 \mathrm{a}$ and $4 \mathrm{~b}$.

\subsection{Selection and use of azeotropic breaking agents}

The review of options for $\mathrm{MeCN}$ recovery from aqueous waste identified the use of azeotropic distillation as the approach with the greatest potential, in the short to medium 
term, to address problems in $\mathrm{MeCN}$ supply. To further examine the feasibility of this approach within the context of pharmaceutical processing, the following ICH Class 3 solvents were considered as breaking agents: acids (acetic and formic acid), ketones (acetone, methyl ethyl ketone, methyl isobutyl ketone), ethers (MTBE, diethyl ether), alcohols (1propanol, 1-pentanol, 2-methyl-1-propanol, n-butanol, ethanol, 2-butanol , 2-propanol and 3methyl-1-butanol), esters (methyl acetate, isopropyl acetate, n-butyl acetate, isobutyl acetate, ethyl acetate, ethyl formate, n-propyl acetate) and others (DMSO, n-pentane, n-heptane). Since batch distillation is the most commonly used approach to separation and purification in the pharmaceutical industry, these solvents were screened according to the practical entrainer selection rules and guidelines for heteroazeotropic batch distillation described by Skouras et al. ${ }^{51}$ and summarised below:

- Entrainer selection rule 1: "The entrainer should form a heteroazeotrope with one of the original components and/or a ternary heteroazeotrope."

- Entrainer selection rule 2: "The vertex of the original component to be obtained in the still at steady-state should be connected with the steady-state reflux point of the entrainer-rich phase, with a distillation line in the direction of increasing temperature from the top of the column to the bottom."

- Guideline 1: "The entrainer must not lead to the formation of maximum azeotropes with any of the original components."

- Guideline 2: The entrainer should preferably not lead to the formation of a ternary saddle homoazeotrope."

Two examples of the residue curve maps (RCM) generated for the (a) MeCN-water-MTBE system and (b) MeCN-water-N-propyl acetate system are shown in Figure 3 to illustrate the application of the entrainer selection rules. The first RCM illustrates that MTBE passes each of the entrainer rules and guidelines and, therefore, has potential for the separation of $\mathrm{MeCN}$ and water. On the other hand, N-propyl acetate fails the second entrainer selection rule and is not suitable as an entrainer in this system. For brevity, the detailed results of the entrainer screening for several other ICH Class 2 and Class 3 solvents can be found in the supporting information. Three solvents emerged from the entrainer screening study as potential candidates: MTBE, n-pentane and ethyl formate. Tables $4 \mathrm{a}$ and $4 \mathrm{~b}$ provide information on the binary and ternary azeotropes for several mixtures involving water and/or $\mathrm{MeCN}$ to illustrate how a tactical separation of $\mathrm{MeCN}$ could be planned for a mixed solvent system with MTBE and the previously investigated BuOAc. Due to the likely harsh environment in 
a multi-compound solvent distillation it is probably best to avoid esters due to hydrolysis. In the case of ethyl formate, under the wrong conditions carbon monoxide and hydrogen may be formed, presenting a significant safety issue. N-pentane has not been considered due to its relatively high volatility and special conditions needed to contain it.

\subsection{Ionic liquids as alternative azeotropic breaking agents}

In the review of $\mathrm{MeCN}$ recovery options above, the use of ionic liquids as azeotropic breaking agents was identified as a previously unexplored route with significant potential. In this work, a range of 51 ionic liquids were initially screened, using the predictive COSMO$\mathrm{RS}$ approach, for their ability to break the $\mathrm{MeCN}$-water azeotrope. These ionic liquids were chosen as they are reasonably well characterised and can be purchased from major ionic liquid suppliers. The structures of these ionic liquids are shown in Chart 1. Initially, the vapour-liquid equilibria of the $\mathrm{MeCN}$-water system were simulated at atmospheric pressure using the COSMO-RS method. In order to check the validity of the simulations, a series of VLE experiments were carried out using the apparatus shown in Figure 4, with the x-y plot for the experimental and predicted VLE shown in Figure 5. There is good agreement between the COSMO-RS model and the experimentally determined VLE values for the MeCN-water system, including the accurate detection of the azeotrope point at approximately 0.7 mole fraction $\mathrm{MeCN}$ and $351 \mathrm{~K}$. On the basis of this validation, a series of simulations were performed on the VLE of the MeCN-water system with varying amounts of 51 different ionic liquids added. A summary of the results obtained from the predictive screening calculations is shown in Table 5. It is observed that the ability to break the $\mathrm{MeCN}$-water azeotrope is strongly dependent on the anion of the ionic liquid. For example, with the series of $\left[\mathrm{C}_{4} \mathrm{mim}\right]^{+}$ based ionic liquids, the following general anionic trend is observed (from most effective to least effective):

$$
\begin{gathered}
{[\mathrm{Cl}]^{-} \approx\left[\mathrm{CH}_{3} \mathrm{COO}\right]^{-}>\left[\mathrm{CF}_{3} \mathrm{COO}\right]^{-}>[\mathrm{Br}]^{-} \approx[\mathrm{Tos}]^{-}>\left[\mathrm{NO}_{3}\right]^{-}>\left[\mathrm{MeSO}_{4}\right]^{-} \approx\left[\mathrm{EtSO}_{4}\right]^{-}>[\mathrm{OTf}]^{-}>} \\
{\left[\mathrm{BF}_{4}\right]^{-}>\left[\mathrm{NTf}_{2}\right]^{-}}
\end{gathered}
$$

The observed order coincides with the inverse of the trend found in ionic liquid hydrophobicity, which studies ${ }^{52}$ have shown increases from $\left[\mathrm{NTf}_{2}\right]^{-}>\left[\mathrm{BF}_{4}\right]^{-}>[\mathrm{I}]^{-}>[\mathrm{Cl}]^{-}$. Furthermore, the decrease in azeotrope breaking ability with increasing cation length for ionic liquids based on the $\left[\mathrm{BF}_{4}\right]^{-}$anion mirrors the decrease in hydrophilicity with increasing chain length. ${ }^{53}$ This indicates that the affinity of the ionic liquid towards water plays a 
crucial role in its ability to break the $\mathrm{MeCN}$-water azeotrope. Comparison of the sigma surfaces for some of the anions investigated, shown in Figure 6, suggests that anions which contain areas of high electron density tend to be more suitable for breaking the azeotrope of the $\mathrm{MeCN}$-water system. In addition to the ionic liquids screened, COSMO-RS was used to predict the azeotrope breaking ability of two common salts, $\left[\mathrm{NH}_{4}\right][\mathrm{Cl}]$ and $\left[\mathrm{NH}_{4}\right]\left[\mathrm{CH}_{3} \mathrm{COO}\right]$. The results coincide with the behaviour of ionic liquids containing the same anions however these ammonium salts can easily decompose to form $\mathrm{HCl}$, ammonia or acetic acid, leading to corrosion issues.

Whilst the effect of an ionic liquid on the VLE of the MeCN-water system is clearly the primary factor in determining the optimal breaking agent, cost is also a key consideration. The costs of ionic liquids vary widely, by several orders of magnitude, mainly due to their relative novelty and the lack of large scale processes for their manufacture. As an indication, relative costs based on typical laboratory prices of the various ionic liquids are also shown on Table 5, although caution should be exercised since the relative bulk manufacturing costs of the ionic liquids may differ significantly from the relative laboratory prices. Other potential issues which may affect the suitability of specific ionic liquids for use as entrainers, such as high viscosity, corrosive nature or chemical instability, are also detailed in Table 5.

In order to provide some validation to the predictive screening results, three ionic liquids were chosen for experimental investigation. $\left[\mathrm{P}_{6,6,6,14}\right] \mathrm{Cl}$ and $\left[\mathrm{C}_{8} \mathrm{mim}\right] \mathrm{Cl}$ were chosen due to their promising screening results, relatively low cost and ease of availability. To provide a validation at the other end of the scale, $\left[\mathrm{N}_{2,2,2,8}\right]\left[\mathrm{NTf}_{2}\right]$ was chosen as an ionic liquid which was not able to break the MeCN-water azeotrope. The VLE results are shown in Figure 5, Figure 7 and Figure 8 respectively. Due to the non-volatile nature of ionic liquids, the VLE can be represented using a typical binary $\mathrm{x}-\mathrm{y}$ plot for $\mathrm{MeCN}$ and water, rather than using the residue curve maps shown previously. In all cases, the results suggest that COSMO-RS is qualitatively useful in predicting the VLE data for the IL-MeCN-water systems. In the case of $\left[\mathrm{C}_{8} \mathrm{mim}\right] \mathrm{Cl}$, the experimental data closely maps the VLE predictions. For $\left[\mathrm{N}_{2,2,2,8}\right]\left[\mathrm{NTf}_{2}\right]$, only one equilibrium point was experimentally determined, at a liquid phase composition of 0.9 mole fraction of $\mathrm{MeCN}$, which illustrates that the azeotrope is not broken in the presence of the ionic liquid, thus corroborating the predictive screening results. 
Table 6 summaries the previous discussion by identifying the leading options for the recovery of $\mathrm{MeCN}$ from the $\mathrm{MeCN}$-water-toluene system. For recovery to take place at a manufacturing site then the best use of multi-purpose plant is required. To this end, maximising the relative volatility and simplicity of equipment in a cGMP environment, minimising the cost of breaking agent and guaranteeing process robustness will lead to the best solution. From Table 6, the best external solution is multistage distillation with or without a breaking agent whilst internally the better solution may be to use an ionic liquid in conventional batch processing equipment.

\section{Conclusions}

This study has highlighted the importance of $\mathrm{MeCN}$ in the pharmaceutical industry and illustrated the need for implementation of recovery and recycle steps to improve its environmental profile and reduce exposure to supply volatility. It has been demonstrated that it is possible and feasible to recover and recycle $\mathrm{MeCN}$ from aqueous waste streams and ensure that the use of this process solvent is sustainable from a corporate social responsibility viewpoint. Several Class 3 solvents have been identified as potential entrainers in the distillation of $\mathrm{MeCN}$-water mixtures. A number of recommendations have been made that would be helpful to toll convertors or commercial manufacturing organisations (CMO). It is unlikely that pharmaceutical grade $\mathrm{MeCN}$ can be manufactured and tactically recycled $\mathrm{MeCN}$ should be used in industries other than the pharmaceutical industry. Moreover, it has been demonstrated that the predictive science approach to the opportunities presented by $\mathrm{MeCN}$ sustainability allows novel technologies that are under development to be assessed quickly for viability and commercial success. In this way, the potential of ionic liquids as "designer" entrainers to enable the recovery and recycle of $\mathrm{MeCN}$ has been illustrated. The need for further investigation into the relevant safety, environmental and processing implications of ionic liquids in pharmaceutical processes to establish their potential utility in the medium-to-long term has been highlighted. Several alternative routes to manufacturing $\mathrm{MeCN}$ have also been highlighted and this approach merits further investigation to tackle the current supply issues associated with producing $\mathrm{MeCN}$ as a side product.

\section{Experimental and computational methodology}

$\mathrm{MeCN}$ and toluene used in the current study were obtained from Sigma Aldrich with purity in excess of $98 \%$. $\left[\mathrm{P}_{6,6,6,14}\right][\mathrm{Cl}]$ was provided by $\mathrm{Cytec}$ and used as received. $\left[\mathrm{C}_{6} \mathrm{mim}\right][\mathrm{Cl}]$ and 
$\left[\mathrm{C}_{8} \operatorname{mim}\right][\mathrm{Cl}]$ were synthesised within QUILL by alkylation of 1-methylimidazole with the appropriate alkyl chloride according to previously reported procedures. ${ }^{54}\left[\mathrm{~N}_{2,2,2,8}\right]\left[\mathrm{NTf}_{2}\right]$ was synthesised within QUILL by the analogous reaction of triethyl amine with octyl iodide followed by the metathesis reaction with lithium bis(trifluoromethane)sulfonimide according to previously reported procedures. ${ }^{54}$

VLE experiments were carried out to verify predicted results using the apparatus in Figure 4. This experimental set-up was initially validated by measuring VLE for the $\mathrm{MeCN} /$ water system and comparing with data available in the literature ${ }^{55}$ as shown in Figure 5. Furthermore, to validate the experimental set-up for ionic liquid-containing systems, the VLE of the ethanol/water/[ $\left.\mathrm{C}_{6} \mathrm{mim}\right][\mathrm{Cl}]$ system was measured and compared with literature data. ${ }^{\text {Error! Bookmark not defined. }}$ These results are shown in the supporting information. To obtain each point on the equilibrium curve, $50 \mathrm{ml}$ of $\mathrm{MeCN} /$ water binary mixture with a known composition was weighed out using a Denver SI-234 balance and added to the VLE apparatus along with a stirrer bar. The flask was then placed in a heating block and fitted with a thermocouple and condenser. A $5 \mathrm{ml}$ sample vial was fitted to the reflux tap to collect the condensed phase while the liquid phase was collected using a $5 \mathrm{ml}$ syringe. The system was then insulated and heated to boiling point and allowed to reflux for 15 minutes insuring equilibrium was reached. After 15 minutes the temperature was recorded and $2 \mathrm{ml}$ samples were taken from both the liquid and condensed phases and allowed to cool. The content of the top and bottom phases were analysed by NMR using a Bruker $300 \mathrm{MHz}$ spectrometer. A small amount from each sample collected was added to NMR tubes along with a deuterated DMSO probe and submitted for proton analysis. The composition of each sample was obtained by quantitative analysis of the integrated NMR spectra. The quantitative accuracy of NMR for the MeCN/water/IL system was verified by analysing a range of ternary mixtures of known composition and the uncertainty was estimated to be $\pm 5 \%$.

Residue curve maps were generated using UNIFAC and UNIQUAC thermodynamic packages within Aspen Plus v. 7.2. COSMO calculations were performed on each individual ion or molecule using the TURBOMOLE ${ }^{56}$ quantum chemistry package. Computations were carried out on the density functional theory (DFT) level, using the BP functional ${ }^{57},{ }^{58}$ with a triple-valence polarised basis set (TZVP). ${ }^{59}$ Where applicable, optimised radii ${ }^{60}$ were used in the COSMO calculation $(\mathrm{H}=1.30, \mathrm{C}=2.00, \mathrm{~N}=1.83, \mathrm{O}=1.72, \mathrm{~F}=1.72, \mathrm{~S}=2.16, \mathrm{Cl}=2.05$, $\mathrm{Br}=2.16, \mathrm{I}=2.32$ ); otherwise, $1.17 \mathrm{xvdW}$ radii were used. COSMO-RS thermodynamic predictions of VLE were generated using COSMOthermX software. 


\section{References}

7
8
9

10

11

12

13

14

15

16

17

18

19

20

21

22

23

24

25

26

27

28

29

30

31

32

33

34

35

36

37

38

39

40

41

42

43

44

45

46

47

48

49

50

51

52

53

54

55

56

57

58

59

60

McConvey et al. 
${ }^{1}$ Bonilla, R. Cost effective solutions to the world wide MeCN shortage. http://www.pharmpro.com/articles/2010/04/Cost-Effective-Solutions-to-the-World-WideMeCN-Shortage/ (accessed 10/11/11).

${ }^{2}$ Data from SMSWin software www.capec.kt.dtk.dk

${ }^{3}$ Harris, K. R.; Kanakubo, M.; Woolf, L. A. J. Chem. Eng. Data 2007, 52, 2425.

${ }^{4}$ Wakai, C.; Oleinikova, A.; Ott, M.; Weingartner, W. J. Phys Chem B 2005, 109, 17028.

${ }^{5}$ Ulbert, O.; Frater, T.; Belafi-Bako, K.; Gubicza, L. J. Mol. Cat. B 2004, 31, 39.

${ }^{6}$ Desai, A.M.; Andreae, M.; Mullen, D.G.; Banaszak Holl, M.M.; Baker, Jr., J.R. Anal. Methods, 2011, 3, 56.

${ }^{7}$ MHRA: Global shortage of MeCN: Advice to the pharmaceutical industry on changes requiring variation submissions to update marketing authorisations.

http://www.mhra.gov.uk/Howweregulate/Medicinesregulatorynews/CON036276 (accessed 10/11/11).

${ }^{8}$ Majors, R. E. LCGC North America, June 12009.

${ }^{9}$ Henderson, R. K.; Jimenez-Gonzalez, C.; Constable, D. J. C.; Alston, S. R.; Inglis, G. G. A.; Fisher, G.; Sherwood, J.; Binks, S. P.; Curzons, A. D. Green Chem. 2011, 13, 854.

${ }^{10}$ Klamt, A.; Eckert, F. Fluid Phase Equilib. 2000, 172, 43.

${ }^{11}$ Klamt, A.; Schuurmann, G. J. Chem. Soc., Perkin Trans. 2, 1993, 5, 799.

${ }^{12}$ EU Directive 2008/98/EC. http://eurlex.europa.eu/LexUriServ/LexUriServ.do?uri=OJ:L:2008:312:0003:0003:EN:PDF (accessed 10/11/11).

${ }^{13}$ ICH topic Q3C (R4) Impurities: Guidelines for Residual Solvents. European Medicines Agency.

http://www.ema.europa.eu/docs/en_GB/document_library/Scientific_guideline/2009/09/WC5 00002674.pdf (accessed 10/11/11).

${ }^{14}$ Purdie, E. L.; Young, F. M.; Menzel, D.; Codd, G. A. Toxicon, 2009, 54, 887.

${ }^{15}$ Bordonaba, J. G.; Crespo, P.; Terry, L. A. Food Chem. 2011, 129, 1265.

${ }^{16}$ Venkatasami, G.; Sowa Jr., J. R. Anal. Chim. Acta, 2010, 665, 227.

${ }^{17}$ Downes, K.; Terry, L. A. Talanta, 2010, 82, 118.

${ }^{18}$ European Commission SCOEL/SUM/130.

http://ec.europa.eu/social/BlobServlet?docId=6408\&langId=en (accessed 10/11/11).

${ }_{19}$ Acosta-Esquijarosa, J.; Rodriguez-Donis, I.; Jauregui-Haza, U.; Nuevas-Paz, L.; PardilloFontdevila, E. Sep. Purif. Technol. 2006, 52, 95.

${ }^{20}$ Del Pozo Gomez, M. T.; Klein, A.; Repke, J.-U.; Wozny, G. Desalination 2008, 224, 28.

${ }^{21}$ Bernot, C.; Doherty, M. F.; Malone, M. F. Chem. Eng. Sci. 1991, 46, 1311.

${ }^{22}$ Dussel, R.; Stichlmair, J. Comput. Chem. Eng. 1995, 19, 113.

${ }^{23}$ Rodriguez-Donis, I.; Gerbaud, V.; Joulia, X. Ind. Eng. Chem. Res. 2001, 40, 2729.

${ }^{24}$ Rodriguez-Donis, I.; Pardillo-Fontdevila, E.; Gerbaud, V.; Joulia, X. Comput. Chem. Eng. 2001, 25, 799 .

${ }^{25}$ Rodriguez-Donis, I.; Esquijarosa, J. A.; Gerbaud, V.; Joulia, X. AIChE J. 2003, 49, 3074.

${ }^{26}$ Leggett, D. C.; Jenkins, T. F.; Miyares, P. H. Anal. Chem. 1990, 62, 1355.

${ }^{27}$ Gu, Y.; Shih, P.-H. Enzyme Microb. Tech. 2004, 35, 592.

${ }^{28}$ Zhang, D.; Zhang, Y.; Wen, Y.; Hou, K.; Zhao, J. Chem. Eng. Res. Des. 2011, 89, 2147.

${ }^{29}$ Wang, B.; Ezejias, T.; Feng, H.; Blaschek, H. Chem. Eng. Sci. 2008, 63, 2595.

${ }^{30}$ Dhamole, P. B.; Mahajan, P.; Feng, H. Process Biochem. 2010, 45, 1672.

${ }^{31}$ Fredlake, C. P.; Crosthwaite, J. M.; Hert, D. G.; Aki, S. N. V. K.; Brennecke, J.F. J. Chem. Eng. Data 2004, 49, 954. 
${ }^{32}$ Luis, P.; Ortiz, I.; Aldaco, R.; and Irabien, A. Ecotox. Environ. Safe. 2007, 67, 423.

${ }^{33}$ Periero, A. B.; Araujo, J. M. M.; Esperanca, I. M.; Marrucho, I. M.; Rebelo, L. P. N. J. Chem. Thermodyn. 2012, 46, 2.

${ }^{34}$ Pfenning, D.; Woermann, D.; J. Membrane Sci. 1987, 32, 105.

${ }^{35}$ Hoof, V. V.; Dotremont, C. Buekenhoudt, A. Sep. Purif. Technol. 2006, $48,304$.

${ }^{36}$ Khayet, M.; Cojocaru, C.; Zakrzewska-Trnadel, G. Sep. Purif. Technol. 2008, 63, 303.

${ }^{37}$ Mandal, M. K.; Sant, A. B.; Bhattacharya, P. K. Colloid Surface A 2011, 373, 11.

${ }^{38}$ InPharm. Bayer has solution for solvent shortage in pharma.

http://www.inpharm.com/news/bayer-has-solution-solvent-shortage-pharma (accessed Aug 1 2011).

${ }^{39}$ Erben, H.-G. What about acetonitrile? Speciality Chemicals Magazine, September 2009.

${ }^{40}$ Zhang, Y.; Zhang, Y.; Feng, C.; Qiu, C.; Wen, Y.; Zhao, J. Cat. Commun. 2009, 10, 1454.

${ }^{41}$ Li, Y. J.; Armor, J. N. Chem Commun. 1997, 2013.

${ }^{42}$ Li, Y. J.; Armor, J. N. J. Catal. 1998, 173, 511.

${ }^{43}$ Li, Y. J.; Armor, J. N. J. Catal. 1998, 176, 495.

${ }^{44}$ Li, Y. J.; Armor, J. N. Appl. Catal. A-Gen. 1999, 183, 107.

${ }^{45}$ Li, Y. J.; Armor, J. N. Appl. Catal. A-Gen. 1999, 188, 211.

${ }^{46}$ Rojas, E.; Guerrero-Perez, M. O.; Banares, M. A. Cat. Commun. 2009, 10, 1555.

${ }^{47}$ Fredenslund. Aa.; Jones, R.; Prausnitz, J. M. AIChE J. 1975, 21, 1086

${ }^{48}$ Hahnenkamp, I.; Graubner, G.; Gmehling, J. Int. J. Pharm. 2009, 10, 1555.

${ }^{49}$ Banerjee, T.; Singh, M. K.; Khanna, A. Ind. Eng. Chem. Res. 2006, 45, 3207.

${ }^{50}$ Di Cave, S.; Mazzarotta, B. J. Chem. Eng. Data 1991, 36, 298.

${ }^{51}$ Skouras, S.; Kiva, V.; Skogestad, S. Chem. Eng. Sci. 2005, 60, 2895.

${ }^{52}$ Huddleston, J.G.; Visser,A. E.; Reichert, W. M.; Willauer, H. D.; Broker, G.A.;

Rogers,R.D. Green Chem. 2001, 3, 156.

${ }^{53}$ Holbrey,J.D.; Seddon, K. R. J. Chem. Soc., Dalton Trans. 1999, 2133.

${ }^{54}$ Bonhote, P.; Dias, A.-P.; Papageorgiou, N.; Kalyanasundaram, K.; Gratzel, M. Inorg.

Chem. 1996, 35, 1168.

${ }^{55}$ Blackford,D.S.; York, R. J. Chem. Eng. Data 1965, 10, 313-318.

${ }^{56}$ Ahlrichs, R.; Bar, M.; Haser, M.; Horn, H.; Kolmel, C. Chem. Phys. Lett. 1989, 162, 165.

${ }^{57}$ Perdew, J. P. Phys. Rev. B 1986, 33, 8822.

${ }^{58}$ Vosko, S. H.; Wilk, L.; Nusair, M. Can. J. Phys. 1980, 58, 1200.

${ }^{59}$ Scafer, A.; Huber, C.; Ahlrichs, R. J. Chem. Phys. 1994, 100, 5829.

${ }^{60}$ Klamt, A.; Jonas, V.; Burger, T.; Lohrenz, J. C. J. Phys. Chem. A 1998, 102, 5074. 


\author{
Nomenclature \\ $\mathrm{MeCN}$ - Acetonitrile \\ $\mathrm{BuOH}$ - butanol \\ BuOAc - butyl acetate \\ cGMP - current good manufacturing practice \\ COSMO-RS - Conductor-Like Screening Method for Realistic Solvation \\ DCM - dichloromethane \\ DMF - dimethyl formamide \\ DMSO - dimethyl sulfoxide \\ Immisc. - Immiscible \\ HOAc - acetic acid \\ $\mathrm{MeOH}$ - methanol \\ Misc.- Miscible \\ MTBE - methyl tertiary butyl ether \\ $n$ is the known number of protons contained within the functional group \\ NMP - N-methyl pyrrolidinone \\ SHE - Safety, Health and Environment \\ THF - tetrahydrofuran \\ UNIFAC - Universal Functional Activity Coefficient \\ UNIQUAC - Universal Quasi-Chemical
}

\title{
Acknowledgements
}

The help and expertise of Bjorn Herschend (AZ) and William Mackintosh (AZ) is recognised in making this paper possible. The authors would also like to thank Cytec Industries and QUILL for providing the ionic liquids used in this study and DELNI for financial support.

\section{Supporting Information}

Detailed results for entrainer screening of Class 2 and Class 3 solvents can be found in the supporting information spreadsheet. Also included are the experimental results for the water/ethanol $/\left[\mathrm{C}_{6} \mathrm{mim}\right][\mathrm{Cl}]$ system used to validate the VLE apparatus for systems containing ionic liquids. This information is available free of charge via the Internet at http://pubs.acs.org/. 


\section{Tables}

Table 1. Key properties of $\mathrm{MeCN}$ for use as a solvent in the pharmaceutical industry in comparison with other polar solvents. ${ }^{2}$

\begin{tabular}{|c|c|c|c|c|c|c|c|c|c|}
\hline Property & $\mathrm{MeCN}$ & $\mathrm{MeOH}$ & THF & DMSO & DMF & NMP & DCM & {$\left[\mathrm{C}_{4} \mathrm{mim}\right]\left[\mathrm{BF}_{4}\right]$} & Water \\
\hline MW & 41.5 & 32.04 & 72.11 & 78.14 & 73.09 & 99.13 & 84.93 & 226.03 & 18.02 \\
\hline $\begin{array}{l}\text { Normal Boiling } \\
\text { Point }\left({ }^{\circ} \mathrm{C}\right)\end{array}$ & 81.6 & 64.50 & 67.0 & 189.0 & 153.0 & 202.0 & 39.7 & Non-volatile & 100.0 \\
\hline $\begin{array}{l}\text { Kinematic } \\
\text { viscosity* }\left(10^{6}\right. \\
\left.\mathrm{m}^{2} / \mathrm{s}\right) \text { at } 20{ }^{\circ} \mathrm{C}\end{array}$ & 0.49 & 0.75 & 0.62 & 2.0 & 0.98 & 1.62 & 0.33 & $86^{\mathrm{a}}$ & 1.00 \\
\hline $\begin{array}{l}\text { Misicibility } \\
\text { with water }\end{array}$ & Misc. & Misc. & Misc. & Misc. & Misc. & Misc. & Immisc. & Misc. & $\mathrm{n} / \mathrm{a}$ \\
\hline $\begin{array}{l}\text { Dielectric } \\
\text { constant at } 20{ }^{\circ} \mathrm{C}\end{array}$ & 35.94 & 32.66 & 7.58 & 46.45 & 36.7 & 32.20 & 8.93 & $11.7^{b}$ & 80.10 \\
\hline $\log \mathrm{P}$ & -0.34 & -0.74 & 0.46 & -1.35 & -1.01 & -0.38 & 1.25 & $-2.44^{\mathrm{c}}$ & $\mathrm{n} / \mathrm{a}$ \\
\hline $\begin{array}{l}\text { GSK SHE issue } \\
\text { categorisation }^{9}\end{array}$ & $\begin{array}{l}\text { Life } \\
\text { cycle, } \\
\text { waste }\end{array}$ & No issue & $\begin{array}{l}\text { EHS } \\
\text { red flag }\end{array}$ & $\begin{array}{l}\text { Reactivity } \\
\text { \&stability }\end{array}$ & $\begin{array}{l}\text { EHS } \\
\text { red flag }\end{array}$ & $\begin{array}{l}\text { EHS } \\
\text { red flag }\end{array}$ & $\begin{array}{l}\text { EHS } \\
\text { red flag }\end{array}$ & $\mathrm{n} / \mathrm{a}$ & No issue \\
\hline
\end{tabular}

${ }^{\mathrm{a}}$ Reference $3,{ }^{b}$ Reference $4,{ }^{\mathrm{c}}$ Reference 5 
Table 2: Strategies for tackling the MeCN supply problem in the context of the waste minimisation heirarchy, technical feasibility and economic feasibility.

\begin{tabular}{|c|c|c|c|}
\hline Strategy & $\begin{array}{c}\text { EU Waste } \\
\text { Heirarchy } \\
\text { classification } \\
\end{array}$ & $\begin{array}{l}\text { Technical } \\
\text { feasibility }\end{array}$ & $\begin{array}{l}\text { Economic } \\
\text { feasibility }\end{array}$ \\
\hline (a) Do nothing & $\begin{array}{l}\text { Disposal. } \\
\text { Not sustainable } \\
\text { as an option; } \\
\text { relies on the } \\
\text { status quo. } \\
\end{array}$ & $\begin{array}{l}\text { No technical } \\
\text { effort required. }\end{array}$ & $\begin{array}{l}\text { Volatility on } \\
\text { price control } \\
\text { likely to be out } \\
\text { of control. }\end{array}$ \\
\hline $\begin{array}{l}\text { (b) New manufacturing } \\
\text { routes to MeCN (internal or } \\
\text { external) }\end{array}$ & $\begin{array}{l}\text { Disposal. } \\
\text { Supports the } \\
\text { existing } \\
\text { manufacture; } \\
\text { however, not a } \\
\text { very sustainable } \\
\text { approach. }\end{array}$ & $\begin{array}{l}\text { Processing route } \\
\text { requires } \\
\text { excellent SHE } \\
\text { standards. }\end{array}$ & $\begin{array}{l}\text { Difficult to } \\
\text { compete with } \\
\text { MeCN } \\
\text { available from } \\
\text { acrylonitrile } \\
\text { process. }\end{array}$ \\
\hline $\begin{array}{l}\text { (c) External recycling of } \\
\text { MeCN }\end{array}$ & $\begin{array}{l}\text { Recycle. } \\
\text { Energy and } \\
\text { breaking solvent } \\
\text { may be } \\
\text { necessary. }\end{array}$ & $\begin{array}{l}\text { Technical } \\
\text { capability } \\
\text { available at all } \\
\text { scales, although } \\
\text { cGMP may be } \\
\text { an issue. }\end{array}$ & $\begin{array}{l}\text { Use of toll } \\
\text { conversion } \\
\text { should make } \\
\text { this relatively } \\
\text { easy to } \\
\text { achieve. }\end{array}$ \\
\hline $\begin{array}{l}\text { (d) Internal recycling of } \\
\mathrm{MeCN}\end{array}$ & $\begin{array}{l}\text { Recycle. } \\
\text { As above. }\end{array}$ & $\begin{array}{l}\text { May required a } \\
\text { column with a } \\
\text { large number of } \\
\text { contacting } \\
\text { stages. }\end{array}$ & $\begin{array}{l}\text { Process plant } \\
\text { availability } \\
\text { and access } \\
\text { could be a } \\
\text { problem. }\end{array}$ \\
\hline $\begin{array}{l}\text { (e) Reduce MeCN usage } \\
\text { (utilising alternative } \\
\text { solvents, solvent-free } \\
\text { synthesis or alternative } \\
\text { separation techniques) }\end{array}$ & $\begin{array}{l}\text { Prevention. } \\
\text { Longer term, } \\
\text { removal of } \\
\text { MeCN from } \\
\text { processes is the } \\
\text { most sustainable } \\
\text { option, } \\
\text { providing good } \\
\text { alternatives can } \\
\text { be established. }\end{array}$ & $\begin{array}{l}\text { Culture change } \\
\text { required, } \\
\text { especially at the } \\
\text { organic process } \\
\text { synthetic } \\
\text { chemistry level. }\end{array}$ & $\begin{array}{l}\text { Longer term } \\
\text { economic } \\
\text { feasability } \\
\text { should be } \\
\text { better. }\end{array}$ \\
\hline
\end{tabular}


Table 3. Overview of recent research reported in the literature on the replacement or recovery of $\mathrm{MeCN}$

\begin{tabular}{|c|c|c|c|}
\hline $\begin{array}{l}\text { Research/Development } \\
\text { Area }\end{array}$ & Method & Technical feasibility & $\begin{array}{l}\text { Economic } \\
\text { feasibility }\end{array}$ \\
\hline \multirow[t]{2}{*}{ (a) Solvent Substitution } & $\begin{array}{l}\text { Methanol } \\
\text { HPLC14 }\end{array}$ & \multirow{2}{*}{$\begin{array}{l}\text { Only tested in a limited } \\
\text { number of areas. More } \\
\text { research needed to } \\
\text { ensure management of } \\
\text { change. }\end{array}$} & \multirow{2}{*}{$\begin{array}{l}\mathrm{MeOH}(£ 13.50)^{*<} \\
\text { ethanol }(£ 49.80)^{*<} \\
\text { MECN }(£ 72.60)^{*}\end{array}$} \\
\hline & $\begin{array}{l}\text { Ethanol } \\
\text { HPLC }^{17}\end{array}$ & & \\
\hline \multirow{4}{*}{$\begin{array}{l}\text { (b) Azeotropic Distillation } \\
\text { for recycle }\end{array}$} & $\begin{array}{l}\text { Entrainer } \\
\text { Screening }\end{array}$ & $\begin{array}{l}\text { Well researched and } \\
\text { understood however } \\
\text { entrainer optimisation } \\
\text { is difficult. }\end{array}$ & $\begin{array}{l}\text { In line with strategy } \\
\text { (b) and (c) of table } 2\end{array}$ \\
\hline & Ionic Liquids ${ }^{33}$ & $\begin{array}{l}\text { Good reputation as } \\
\text { azeotrope breakers } \\
\text { however not tested for } \\
\text { aqueous nitrile systems }\end{array}$ & $\begin{array}{l}\text { Large amounts of } \\
\text { expensive IL may be } \\
\text { required. }\end{array}$ \\
\hline & Salting Out ${ }^{26-28}$ & $\begin{array}{l}\text { May present corrosion } \\
\text { issues }\end{array}$ & Relatively low cost \\
\hline & ${ }_{30}^{\text {Sugaring Out }}{ }^{29-}$ & $\begin{array}{l}\text { A promising and recent } \\
\text { development area } \\
\text { which requires further } \\
\text { work. }\end{array}$ & Cheaper than salt \\
\hline \multirow{2}{*}{$\begin{array}{l}\text { (c) Physical Separations } \\
\text { for recycle }\end{array}$} & $\begin{array}{l}\text { Pervaporation } \\
36\end{array}$ & $\begin{array}{l}\text { Problems in producing } \\
\text { commercially available } \\
\text { and solvent stable } \\
\text { membranes. }\end{array}$ & Low OPEX \\
\hline & $\begin{array}{l}\text { Pervaporation } \\
\text { Distillation }^{20}\end{array}$ & $\begin{array}{l}\text { Problems with } \\
\text { temperature and } \\
\text { concentration } \\
\text { polarisation effects. }\end{array}$ & $\begin{array}{l}\text { Avoids use of } \\
\text { entrainers which can } \\
\text { prove difficult to } \\
\text { purify and recycle. }\end{array}$ \\
\hline \multirow{2}{*}{$\begin{array}{l}\text { (d) Novel Manufacturing } \\
\text { Processes at Feasibility } \\
\text { Stage }\end{array}$} & $\begin{array}{l}\text { Amination of } \\
\text { Ethanol }^{28}\end{array}$ & \multirow[b]{2}{*}{$\begin{array}{l}\text { Processing routes will } \\
\text { require excellent SHE } \\
\text { standards. }\end{array}$} & \\
\hline & $\begin{array}{l}\text { Ammoxidation } \\
\text { of Ethane }{ }^{41-46}\end{array}$ & & $\begin{array}{l}\text { By product of natural } \\
\text { gas thus large scale } \\
\text { production could } \\
\text { prove expensive. }\end{array}$ \\
\hline \multirow{2}{*}{$\begin{array}{l}\text { (e) Commercial } \\
\text { Manufacturing Processes } \\
\text { in place }\end{array}$} & Pilot Plant ${ }^{38}$ & $\begin{array}{l}\text { Plant can produce } \\
\text { around } 4 \mathrm{~m}^{3} / \text { week }\end{array}$ & HPLC grade only \\
\hline & $\begin{array}{l}\text { NITRALZ }{ }^{39} \\
\text { AlzChem }\end{array}$ & In production & HPLC grade only \\
\hline
\end{tabular}

* HPLC grade (or equivalent) prices per litre from Sigma Aldrich 
Table 4a: Azeotropic bubble points $\left({ }^{\circ} \mathrm{C}\right.$ at $\left.1 \mathrm{~atm}\right)$ as predicted by UNIFAC ${ }^{2}$ of solvent mixtures typically encountered in the recovery of $\mathrm{MeCN}$. Shaded cells represent heterogeneous azeotropes.

\begin{tabular}{|c|c|c|c|c|c|c|c|c|}
\hline \multirow[t]{2}{*}{ Solvent } & & & & & & & & \\
\hline & $\mathrm{H}_{2} \mathrm{O}$ & & & & & & & \\
\hline MECN & 75.5 & $\mathrm{MECN}$ & & & & & & \\
\hline Acetone & 56.0 & - & Acetone & & & & & \\
\hline $\mathrm{MeOH}$ & - & 64.1 & 55.3 & $\mathrm{MeOH}$ & & & & \\
\hline Toluene & 84.1 & 80.7 & - & 84.1 & Toluene & & & \\
\hline HOAc & 98.4 & - & - & - & 103.2 & HOAc & & \\
\hline MTBE & 60.5 & 55.8 & 51.9 & 52.4 & - & - & MTBE & \\
\hline BuOAc & 90.7 & - & - & - & - & 116.6 & - & $\mathrm{BuOAc}$ \\
\hline $\mathrm{BuOH}$ & 92.7 & - & - & - & 104.7 & 117.7 & - & 115.1 \\
\hline
\end{tabular}


Table 4b: Ternary azeotropes at $1 \mathrm{~atm}$ as predicted by UNIFAC $^{2}$ for mixtures involving impurity solvents typically encountered in the recovery of $\mathrm{MeCN}$.

\begin{tabular}{|l|l|l|}
\hline Components & Bubble point $\left({ }^{\mathbf{0}} \mathbf{C}\right)$ & Phase behaviour \\
\hline $\mathrm{H}_{2} \mathrm{O} / \mathrm{MeOH} / \mathrm{MTBE}$ & 59.0 & Heterogeneous \\
\hline $\mathrm{H}_{2} \mathrm{O} / \mathrm{MeCN} / \mathrm{MTBE}$ & 60.3 & Heterogeneous \\
\hline $\mathrm{H}_{2} \mathrm{O} / \mathrm{MeOH} /$ toluene & 65.4 & Heterogeneous \\
\hline $\mathrm{H} 2 \mathrm{O} / \mathrm{MTBE} /$ toluene & 67.9 & Homogeneous \\
\hline $\mathrm{H}_{2} \mathrm{O} / \mathrm{MeCN} /$ toluene & 72.4 & Heterogeneous \\
\hline $\mathrm{H}_{2} \mathrm{O} / \mathrm{BuOH} /$ toluene & 83.1 & Heterogeneous \\
\hline $\mathrm{H}_{2} \mathrm{O} / \mathrm{HOAc} /$ toluene & 84.0 & Heterogeneous \\
\hline $\mathrm{H}_{2} \mathrm{O} / \mathrm{BuOAc} / \mathrm{BuOH}$ & 90.1 & Heterogeneous \\
\hline
\end{tabular}


Table 5: Screening of several ionic liquids as entrainers for breaking the MeCN-water azeotrope

\begin{tabular}{|c|c|c|c|c|}
\hline Cation & Anion & $\begin{array}{l}\text { Min. mole fraction } \\
\text { required to break } \\
\text { azeotrope }\end{array}$ & $\begin{array}{l}\text { Cost of ILs } f \text { (relative } \\
\left.\text { to }\left[P_{66614}\right][C l]\right)^{b}\end{array}$ & Issues \\
\hline$\left[\mathrm{P}_{66614}\right]^{+}$ & {$[\mathrm{Cl}]^{-}$} & 0.1 & 1.0 & $\begin{array}{l}\text { Cheap and readily } \\
\text { available }\end{array}$ \\
\hline$\left[\mathrm{C}_{2} \mathrm{mim}\right]^{+}$ & {$[\mathrm{Cl}]^{-}$} & 0.1 & 0.9 & Solid at RT \\
\hline$\left[\mathrm{C}_{4} \mathrm{mim}\right]^{+}$ & {$[\mathrm{Cl}]^{-}$} & 0.1 & 1.3 & Solid at RT \\
\hline$\left[\mathrm{C}_{6} \mathrm{mim}^{+}\right.$ & {$[\mathrm{Cl}]^{-}$} & 0.1 & 1.9 & Viscous at RT \\
\hline$\left[\mathrm{C}_{8} \mathrm{mim}\right]^{+}$ & {$[\mathrm{Cl}]^{-}$} & 0.1 & 1.8 & Viscous at RT \\
\hline$\left[\mathrm{C}_{10} \mathrm{mim}\right]^{+}$ & {$[\mathrm{Cl}]^{-}$} & 0.1 & 2.5 & Viscous at RT \\
\hline$\left[\mathrm{C}_{4} \mathrm{mPy}\right]^{+}$ & {$[\mathrm{Cl}]^{-}$} & 0.1 & 6.9 & \\
\hline$\left[\mathrm{C}_{4} \mathrm{mPyrr}^{+}\right.$ & {$[\mathrm{Cl}]^{-}$} & 0.1 & 3.8 & \\
\hline$\left[\mathrm{N}_{2222}\right]^{+}$ & {$[\mathrm{Cl}]^{-}$} & 0.1 & $\mathrm{n} / \mathrm{a}$ & \\
\hline$\left[\mathrm{N}_{8888}\right]^{+}$ & {$[\mathrm{Cl}]^{-}$} & 0.3 & 19.8 & \\
\hline$\left[\mathrm{C}_{2} \mathrm{mPyrr}\right]^{+}$ & {$[\mathrm{Cl}]^{-}$} & 0.1 & $\mathrm{n} / \mathrm{a}$ & \\
\hline$\left[\mathrm{C}_{2} \mathrm{mim}\right]^{+}$ & {$[\mathrm{Br}]^{-}$} & 0.2 & 1.4 & Solid at RT \\
\hline$\left[\mathrm{C}_{4} \mathrm{mim}\right]^{+}$ & {$[\mathrm{Br}]^{-}$} & 0.2 & 1.3 & \\
\hline$\left[\mathrm{C}_{8} \mathrm{mim}\right]^{+}$ & {$[\mathrm{Br}]^{-}$} & 0.2 & $\mathrm{n} / \mathrm{a}$ & \\
\hline$\left[\mathrm{P}_{66614}\right]^{+}$ & {$[\mathrm{Br}]^{-}$} & 0.3 & 1.0 & \\
\hline$\left[\mathrm{C}_{4} \mathrm{mPyrr}^{+}\right.$ & {$[\mathrm{Br}]^{-}$} & 0.3 & 3.8 & \\
\hline$\left[\mathrm{C}_{2} \mathrm{mim}\right]^{+}$ & {$\left[\mathrm{CH}_{3} \mathrm{COO}\right]^{-}$} & 0.1 & 2.0 & \\
\hline$\left[\mathrm{C}_{4} \mathrm{mim}\right]^{+}$ & {$\left[\mathrm{CH}_{3} \mathrm{COO}\right]^{-}$} & 0.1 & 1.8 & \\
\hline$\left[\mathrm{C}_{8} \mathrm{mim}\right]^{+}$ & {$\left[\mathrm{CH}_{3} \mathrm{COO}\right]^{-}$} & 0.1 & $\mathrm{n} / \mathrm{a}$ & \\
\hline$\left[\mathrm{C}_{4} \mathrm{mim}\right]^{+}$ & {$\left[\mathrm{CF}_{3} \mathrm{COO}^{-}\right.$} & 0.15 & $\mathrm{n} / \mathrm{a}$ & \\
\hline$\left[\mathrm{C}_{8} \mathrm{mim}\right]^{+}$ & {$\left[\mathrm{CF}_{3} \mathrm{COO}\right]^{-}$} & 0.15 & $\mathrm{n} / \mathrm{a}$ & \\
\hline$\left[\mathrm{N}_{2222}\right]^{+}$ & {$\left[\mathrm{CF}_{3} \mathrm{COO}^{-}\right.$} & 0.3 & 23.6 & Corrosive \\
\hline$\left[\mathrm{C}_{4} \mathrm{mPyrr}^{+}\right.$ & {$\left[\mathrm{CF}_{3} \mathrm{COO}^{-}\right.$} & 0.3 & $\mathrm{n} / \mathrm{a}$ & \\
\hline$\left[\mathrm{C}_{2} \mathrm{mim}\right]^{+}$ & {$\left[\mathrm{NO}_{3}\right]^{-}$} & 0.2 & $\mathrm{n} / \mathrm{a}$ & Corrosive \\
\hline$\left[\mathrm{C}_{4} \mathrm{mim}\right]^{+}$ & {$\left[\mathrm{NO}_{3}\right]^{-}$} & 0.2 & 9.3 & \\
\hline$\left[\mathrm{C}_{8} \mathrm{mim}\right]^{+}$ & {$\left[\mathrm{NO}_{3}\right]^{-}$} & 0.25 & $\mathrm{n} / \mathrm{a}$ & \\
\hline$\left[\mathrm{C}_{4} \mathrm{mim}\right]^{+}$ & {$\left[\mathrm{N}(\mathrm{CN})_{2}\right]^{-}$} & 0.4 & 11.5 & \\
\hline$\left[\mathrm{C}_{2} \mathrm{mim}\right]^{+}$ & [Tos $^{-}$ & 0.2 & 4.1 & Corrosive \\
\hline$\left[\mathrm{C}_{4} \mathrm{mim}\right]^{+}$ & {$[\text {Tos }]^{-}$} & 0.2 & 8.6 & $\begin{array}{l}\text { Corrosive to carbon steel } \\
\text { and copper }\end{array}$ \\
\hline$\left[\mathrm{C}_{8} \mathrm{mim}\right]^{+}$ & {$[\text {Tos }]^{-}$} & 0.2 & $\mathrm{n} / \mathrm{a}$ & \\
\hline$\left[\mathrm{C}_{2} \mathrm{mim}\right]^{+}$ & {$\left[\mathrm{MeSO}_{4}\right]^{-}$} & 0.3 & 2.6 & Corrosive \\
\hline
\end{tabular}


28

\begin{tabular}{|c|c|c|c|c|}
\hline$\left[\mathrm{C}_{4} \mathrm{mim}\right]^{+}$ & {$\left[\mathrm{MeSO}_{4}\right]^{-}$} & 0.3 & 1.0 & \\
\hline$\left[\mathrm{C}_{8} \mathrm{mim}^{+}\right.$ & {$\left[\mathrm{MeSO}_{4}\right]^{-}$} & 0.35 & $\mathrm{n} / \mathrm{a}$ & \\
\hline$\left[\mathrm{C}_{2} \mathrm{mim}\right]^{+}$ & {$\left[\mathrm{EtSO}_{4}\right]^{-}$} & 0.3 & 0.7 & $\begin{array}{l}\text { Corrosive to copper and } \\
\text { brass }\end{array}$ \\
\hline$\left[\mathrm{C}_{4} \mathrm{mim}\right]^{+}$ & {$\left[\mathrm{EtSO}_{4}\right]^{-}$} & 0.3 & $\mathrm{n} / \mathrm{a}$ & \\
\hline$\left[\mathrm{C}_{8} \mathrm{mim}\right]^{+}$ & {$\left[\mathrm{EtSO}_{4}\right]^{-}$} & & & \\
\hline$\left[\mathrm{C}_{4} \mathrm{mim}^{+}\right.$ & {$\left[\mathrm{OctSO}_{4}\right]^{-}$} & 0.5 & 2.9 & \\
\hline$\left[\mathrm{C}_{2} \mathrm{mim}^{+}\right.$ & {$\left[\mathrm{BF}_{4}\right]^{-}$} & 0.5 & 1.6 & Potential to hydrolyse \\
\hline$\left[\mathrm{C}_{4} \mathrm{mim}\right]^{+}$ & {$\left[\mathrm{BF}_{4}\right]^{-}$} & 0.6 & 1.0 & Potential to hydrolyse \\
\hline$\left[\mathrm{C}_{10} \mathrm{mim}\right]^{+}$ & {$\left[\mathrm{BF}_{4}\right]^{-}$} & - & $\mathrm{n} / \mathrm{a}$ & Potential to hydrolyse \\
\hline$\left[\mathrm{C}_{2} \mathrm{mPyrr}\right]^{+}$ & {$\left[\mathrm{BF}_{4}\right]^{-}$} & - & $\mathrm{n} / \mathrm{a}$ & Potential to hydrolyse \\
\hline$\left[\mathrm{N}_{2222}\right]^{+}$ & {$\left[\mathrm{BF}_{4}\right]^{-}$} & - & $\mathrm{n} / \mathrm{a}$ & Potential to hydrolyse \\
\hline$\left[\mathrm{C}_{2} \mathrm{mim}^{+}\right.$ & {$[\mathrm{OTf}]^{-}$} & 0.6 & 1.6 & \\
\hline$\left[\mathrm{C}_{4} \mathrm{mim}^{+}\right.$ & {$[\mathrm{OTf}]^{-}$} & 0.6 & 1.6 & \\
\hline$\left[\mathrm{C}_{2} \mathrm{mim}^{+}\right.$ & {$\left[\mathrm{NTf}_{2}\right]^{-}$} & - & 1.6 & $\begin{array}{l}\text { Does not break } \\
\text { azeotrope }\end{array}$ \\
\hline$\left[\mathrm{C}_{4} \mathrm{mim}\right]^{+}$ & {$\left[\mathrm{NTf}_{2}\right]^{-}$} & - & 1.7 & $\begin{array}{l}\text { Does not break } \\
\text { azeotrope }\end{array}$ \\
\hline$\left[\mathrm{C}_{6} \mathrm{mim}\right]^{+}$ & {$\left[\mathrm{NTf}_{2}\right]^{-}$} & - & $\mathrm{n} / \mathrm{a}$ & $\begin{array}{l}\text { Does not break } \\
\text { azeotrope }\end{array}$ \\
\hline$\left[\mathrm{N}_{2228}\right]^{+}$ & {$\left[\mathrm{NTf}_{2}\right]^{-}$} & - & $\mathrm{n} / \mathrm{a}$ & $\begin{array}{l}\text { Does not break } \\
\text { azeotrope }\end{array}$ \\
\hline$\left[\mathrm{NH}_{4}\right]^{+}$ & {$\left[\mathrm{CH}_{3} \mathrm{COO}\right]^{-}$} & 0.1 & $\mathrm{n} / \mathrm{a}$ & $\begin{array}{l}\text { Volatile at low pressures. } \\
\text { Decomposes easily }\end{array}$ \\
\hline$\left[\mathrm{NH}_{4}\right]^{+}$ & {$[\mathrm{Cl}]^{-}$} & 0.1 & $\mathrm{n} / \mathrm{a}$ & Corrosive \\
\hline
\end{tabular}


Table 6: Performance comparison of the different methods for breaking the MeCN-water azeotrope.

\begin{tabular}{|c|c|c|c|c|c|}
\hline $\begin{array}{l}\text { Breaking } \\
\text { agent }\end{array}$ & $\begin{array}{l}\text { Relative } \\
\text { cost/per } \\
\text { amount } \\
\text { breaking } \\
\text { agent }\end{array}$ & $\begin{array}{l}\text { No of } \\
\text { operations }\end{array}$ & $\begin{array}{l}\text { Relative } \\
\text { volatility } \\
\text { of } \mathrm{MeCN}^{*}\end{array}$ & $\begin{array}{l}\text { Ease of } \\
\text { externalisation }\end{array}$ & Robustness \\
\hline None & $\mathrm{N} / \mathrm{A}$ & $\begin{array}{l}\text { Batch } \\
\text { distillation }\end{array}$ & 1 & $\begin{array}{l}\text { Easy at toll } \\
\text { convertor }\end{array}$ & 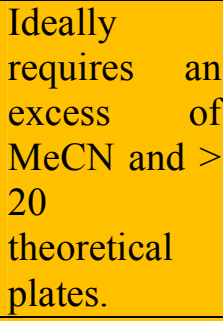 \\
\hline $\mathrm{BuOAc}$ & Low & $\begin{array}{l}\text { Extraction } \\
\text { followed } \\
\text { by batch } \\
\text { distillation }\end{array}$ & $4.1^{*}$ & Easy & $\begin{array}{l}\text { Yes } \\
\text { conventional } \\
\text { processing } \\
\text { with a } \\
\text { number of } \\
\text { vessels used. } \\
\text { Stability of } \\
\text { acetate may } \\
\text { be an issue. }\end{array}$ \\
\hline $\mathrm{NaCl}$ & Low & $\begin{array}{l}\text { Separation } \\
\text { followed } \\
\text { by batch } \\
\text { distillation }\end{array}$ & 8.9 & Easy & $\begin{array}{l}\text { No - requires } \\
\text { large } \\
\text { quantities of } \\
\text { salt and } \\
\text { corrosion } \\
\text { may be an } \\
\text { issue. }\end{array}$ \\
\hline Glucose & Medium & $\begin{array}{l}\text { Separation } \\
\text { followed } \\
\text { by batch } \\
\text { distillation }\end{array}$ & 1.7 & Medium & $\begin{array}{l}\text { No } \\
\text { microbial } \\
\text { growth may } \\
\text { be an issue }\end{array}$ \\
\hline $\begin{array}{l}{\left[\mathrm{C}_{8} \mathrm{mim}\right]} \\
{[\mathrm{CH} 3 \mathrm{COO}]}\end{array}$ & High & $\begin{array}{l}\text { Simple } \\
\text { batch } \\
\text { distillation }\end{array}$ & 9.9 & $\begin{array}{l}\text { Availability } \\
\text { of ionic liquid } \\
\text { may be an } \\
\text { issue in the } \\
\text { short term }\end{array}$ & $\begin{array}{l}\text { Yes - after } \\
\text { development } \\
\text { and may be } \\
\text { possible to } \\
\text { include ionic } \\
\text { liquid in } \\
\text { reaction } \\
\text { phase. }\end{array}$ \\
\hline$\left[\mathrm{C}_{8} \mathrm{mim}\right] \mathrm{Cl}$ & High & $\begin{array}{l}\text { Simple } \\
\text { batch } \\
\text { distillation }\end{array}$ & 4.3 & $\begin{array}{l}\text { Availability } \\
\text { of ionic } \\
\text { liquid. }\end{array}$ & $\begin{array}{l}\text { Yes } \\
\text { above }\end{array}$ \\
\hline
\end{tabular}

*Average relative volatility of $\mathrm{MeCN}$ in $\mathrm{BuOAc}$ 
Chart 1. Structures of the cations and anions in the ionic liquids screened as azeotrope breakers for the $\mathrm{MeCN}$-water system.

Cations :

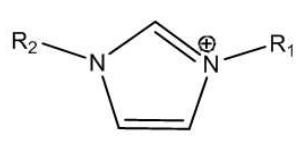

Imidazolium $[\mathrm{im}]^{+}$<smiles>Brc1ccccn1</smiles>

Pyridinium

$[\mathrm{Py}]^{+}$

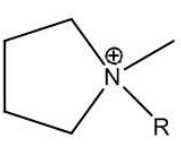

Pyrrolidium $[\mathrm{Pyrr}]^{+}$

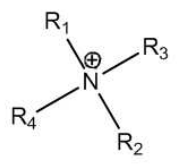

Ammonium

$[\mathrm{N}]^{+}$

Anions :

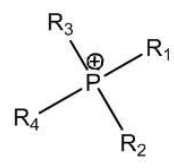

Phosphonium

$[\mathrm{P}]^{+}$

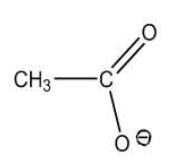

Acetate $\left[\mathrm{CH}_{3} \mathrm{COO}\right]^{-}$
$\mathrm{Cl}^{\ominus}$

Chloride

$[\mathrm{Cl}]^{-}$<smiles>N#COC#N</smiles>

Dicyanamide

$\left[\mathrm{N}(\mathrm{CN})_{2}\right]^{-}$
$\mathrm{Br}^{\ominus}$

Bromide

$[\mathrm{Br}]^{-}$

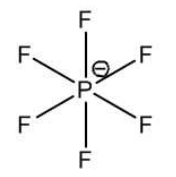

Hexafluorophosphate

$\left[\mathrm{PF}_{6}\right]^{-}$

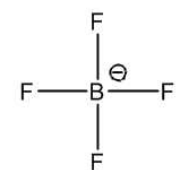

Tetrafluoroborate

$\left[\mathrm{BF}_{4}\right]^{-}$<smiles>Cc1ccc(S(=O)(=O)[O-])cc1</smiles>

Tosylate

$[\mathrm{Tos}]^{-}$ 


\section{Figure Captions}

Figure 1. Comparison between the COSMO $\sigma$-profiles and $\sigma$-surfaces for water, $\mathrm{MeCN}$, hexane and $N$-methyl-2-pyrollidone.

Figure 2: Liquid-liquid equilibria for the $\mathrm{MeCN}+$ water+toluene system at $20{ }^{\circ} \mathrm{C}$ determined from NMR analysis and COSMO-RS simulation and compared with literature values. ${ }^{50}$

Figure 3: Residue curve maps for (a) MeCN-water-MTBE and (b) MeCN-water- $N$-propyl acetate generated using UNIFAC in Aspen Plus.

Figure 4. Experimental set-up used to measure the VLE of the MeCN+water+IL system.

Figure 5. Experimental and COSMO-RS predicted VLE for the MeCN-water system with 0.3 mole fraction $\left[\mathrm{P}_{6,6,6,14}\right][\mathrm{Cl}]$ entrainer compared with the MeCN-water system with no entrainer obtained in this study and from literature. ${ }^{55}$

Figure 6. COSMO $\sigma$-surfaces for the anions $[\mathrm{OTf}]^{-},\left[\mathrm{BF}_{4}\right]^{-}$and $\left[\mathrm{NTf}_{2}\right]^{-}$. The anions are ranked according to their ability to break the $\mathrm{MeCN}$-water azeotrope as determined from the screening results.

Figure 7. Experimental and COSMO-RS predicted VLE for the MeCN-water system with 0.3 mole fraction $\left[\mathrm{C}_{8} \mathrm{mim}\right][\mathrm{Cl}]$ entrainer compared with the $\mathrm{MeCN}$-water system with no entrainer.

Figure 8. Experimental and COSMO-RS predicted VLE for the MeCN-water system with 0.3 mole fraction $\left[\mathrm{N}_{2,2,2,8}\right]\left[\mathrm{NTf}_{2}\right]$ entrainer compared with the MeCN-water system with no entrainer. 


\section{Figures}

Figure 1

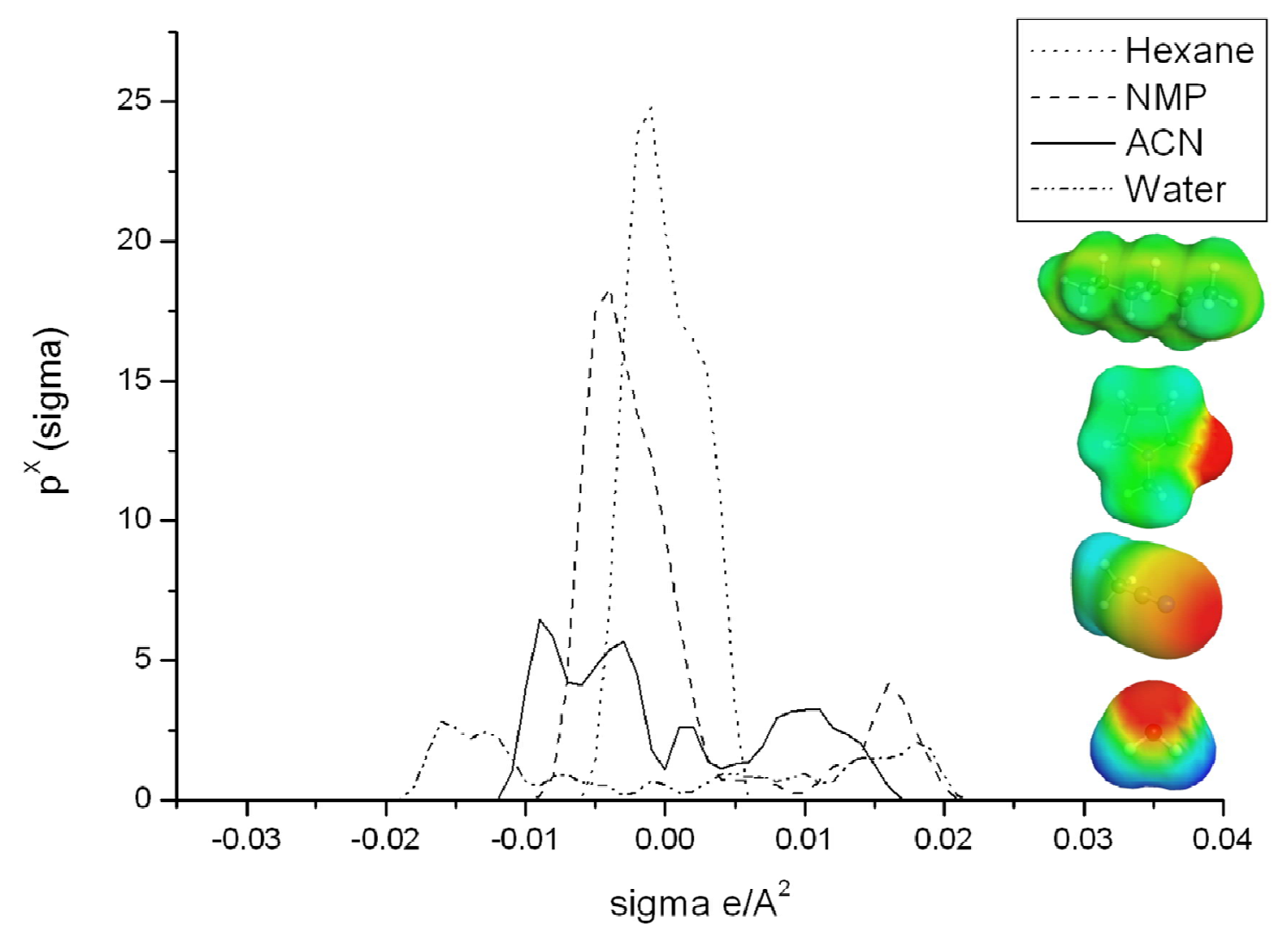

41

42

43

44

45

46

47

48

49

50

51

52

53

54

55

56

57

58

59

60

McConvey et al. 
Figure 2

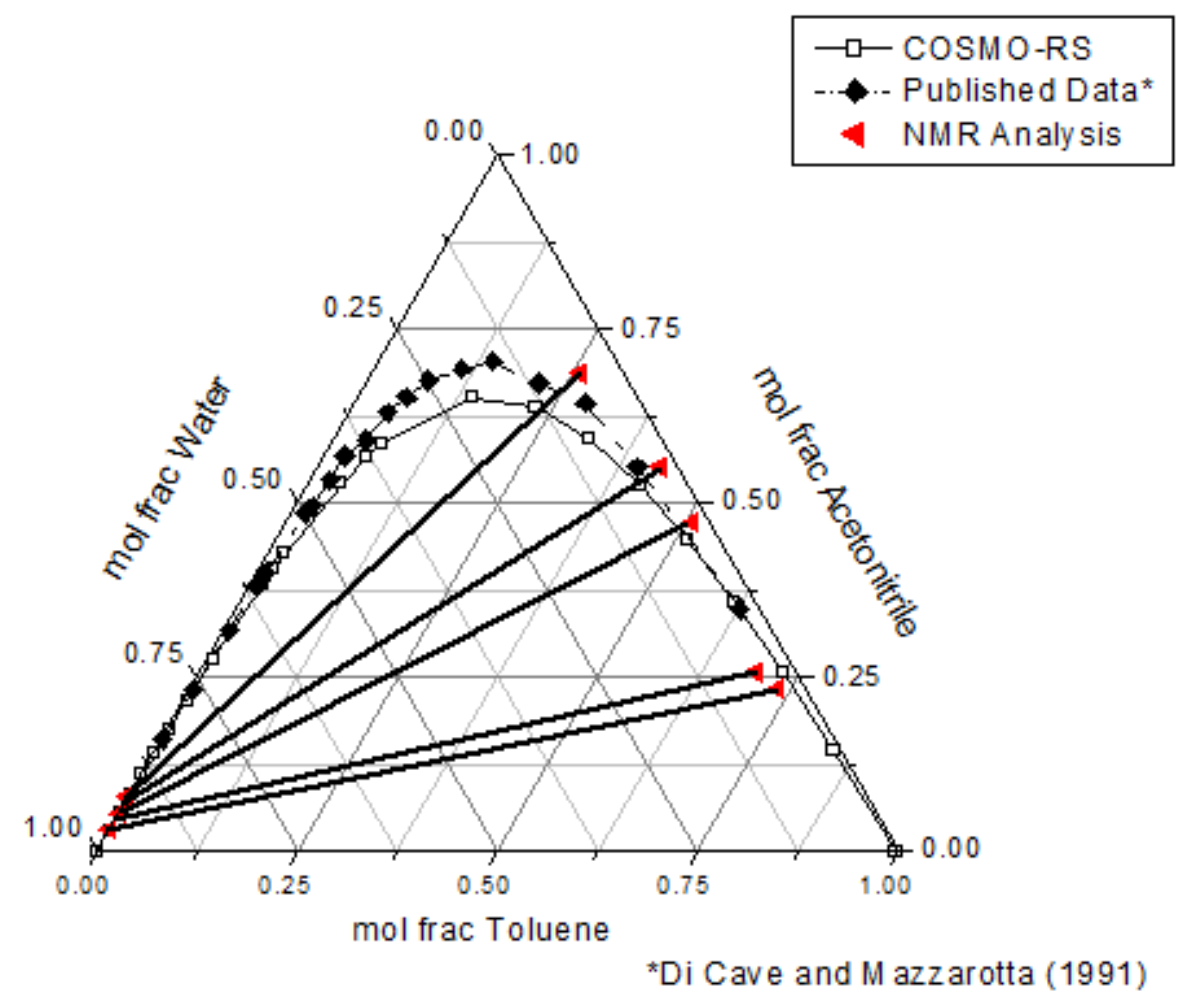


Figure 3
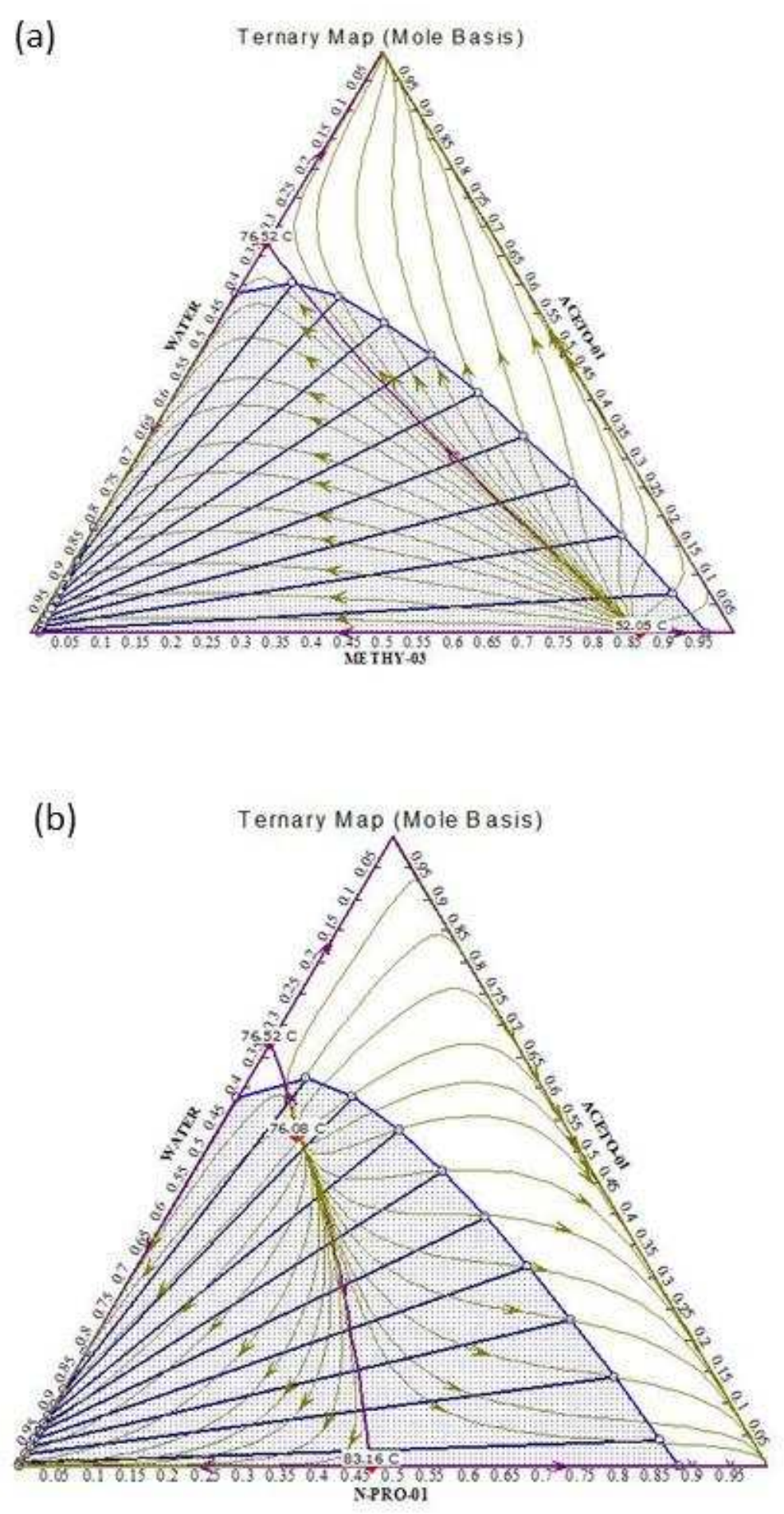
Figure 4

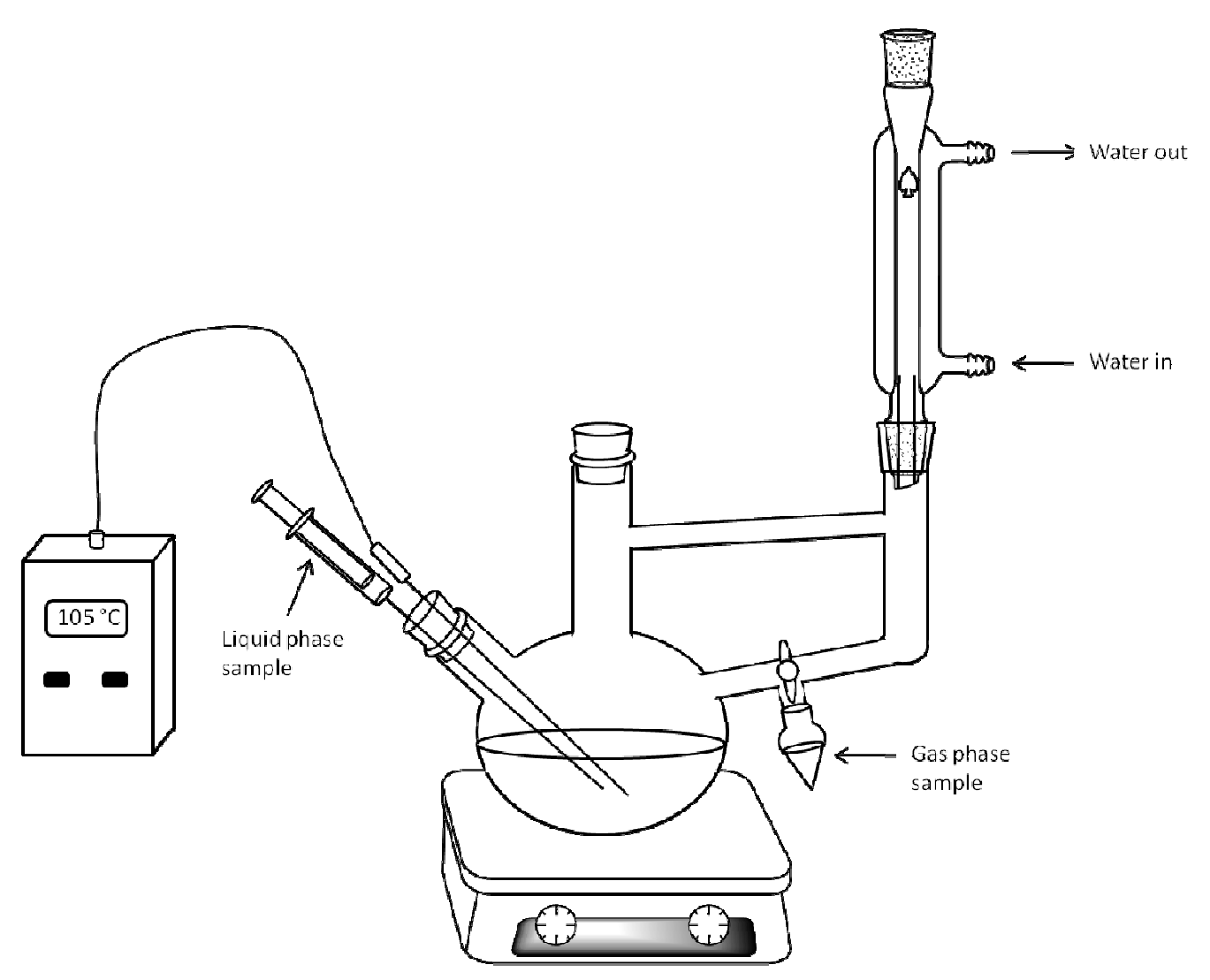

34

35

36

37

38

39

40

41

42

43

44

45

46

47

48

49

50

51

52

53

54

55

56

57

58

59

60

McConvey et al. 
Figure 5

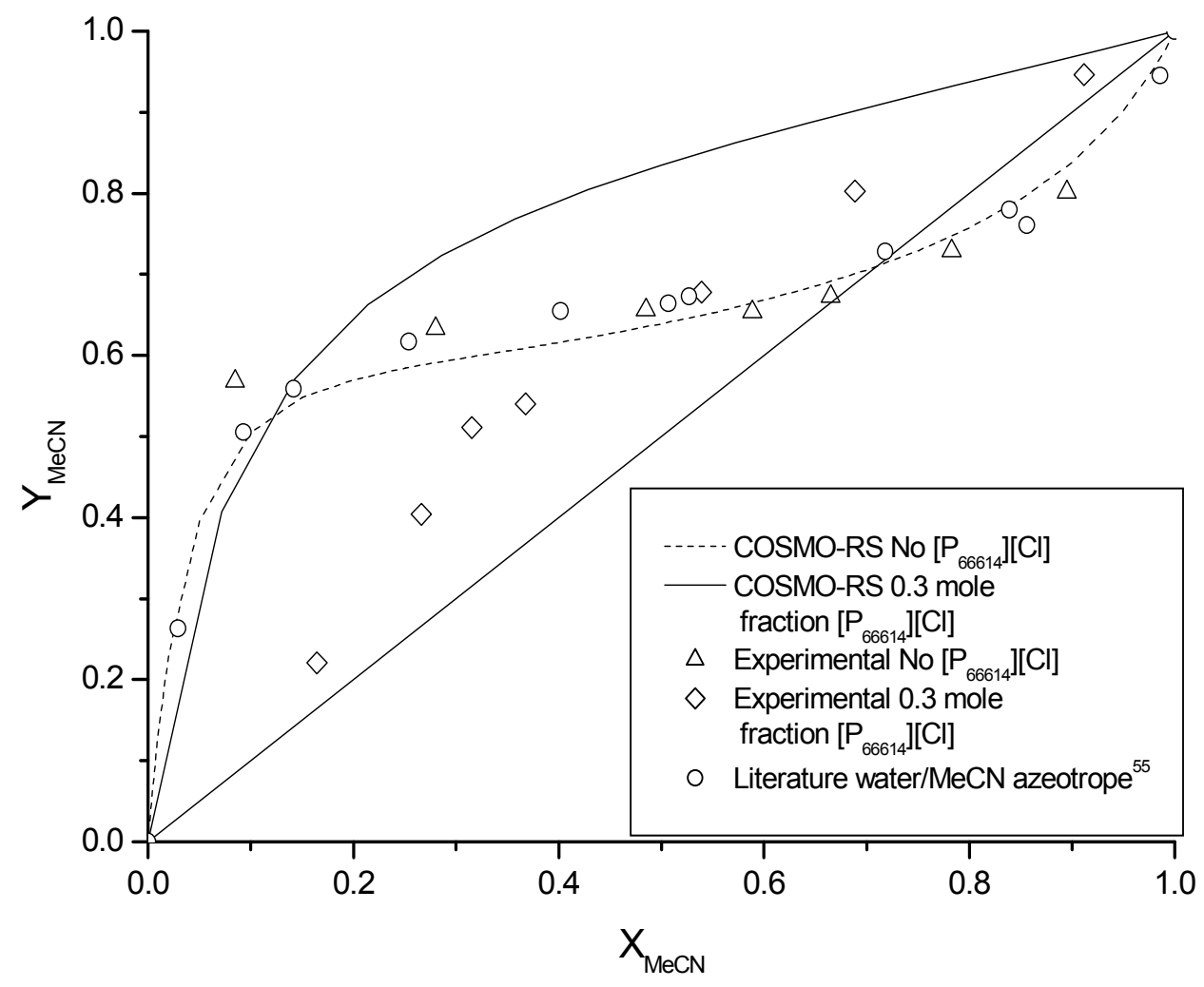


Figure 6

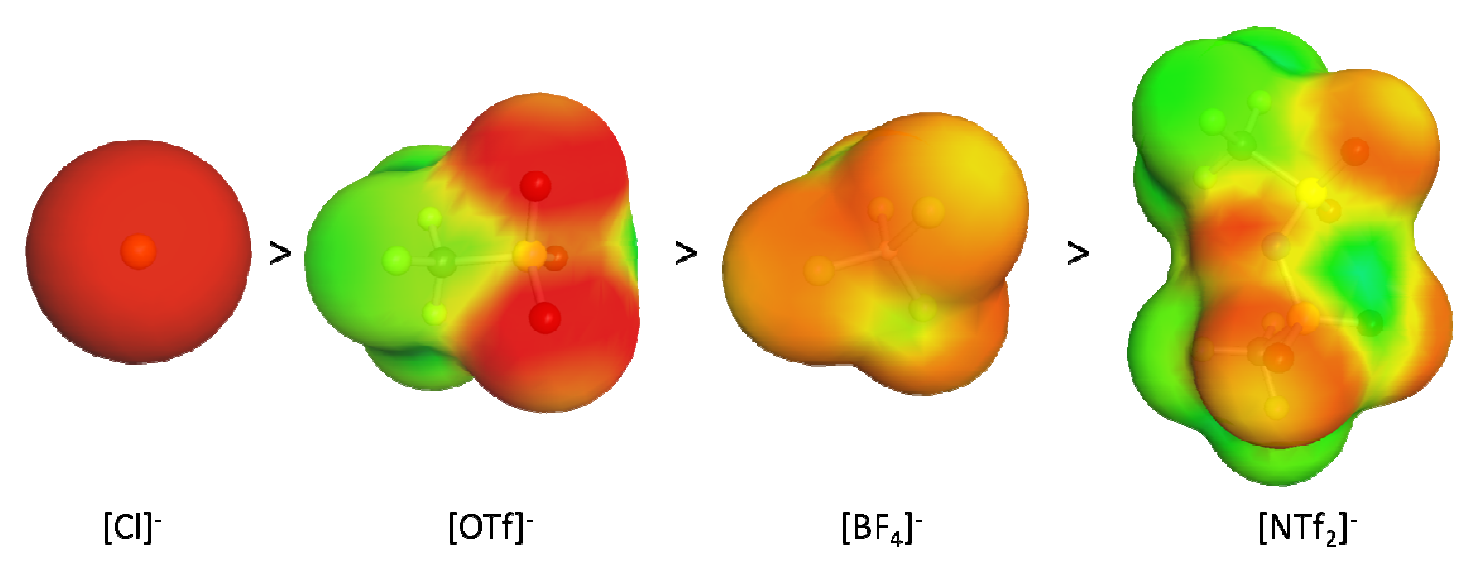

20

21

22

23

24

25

26

27

28

29

30

31

32

33

34

35

36

37

38

39

40

41

42

43

44

45

46

47

48

49

50

51

52

53

54

55

56

57

58

59

60

McConvey et al. 
Figure 7

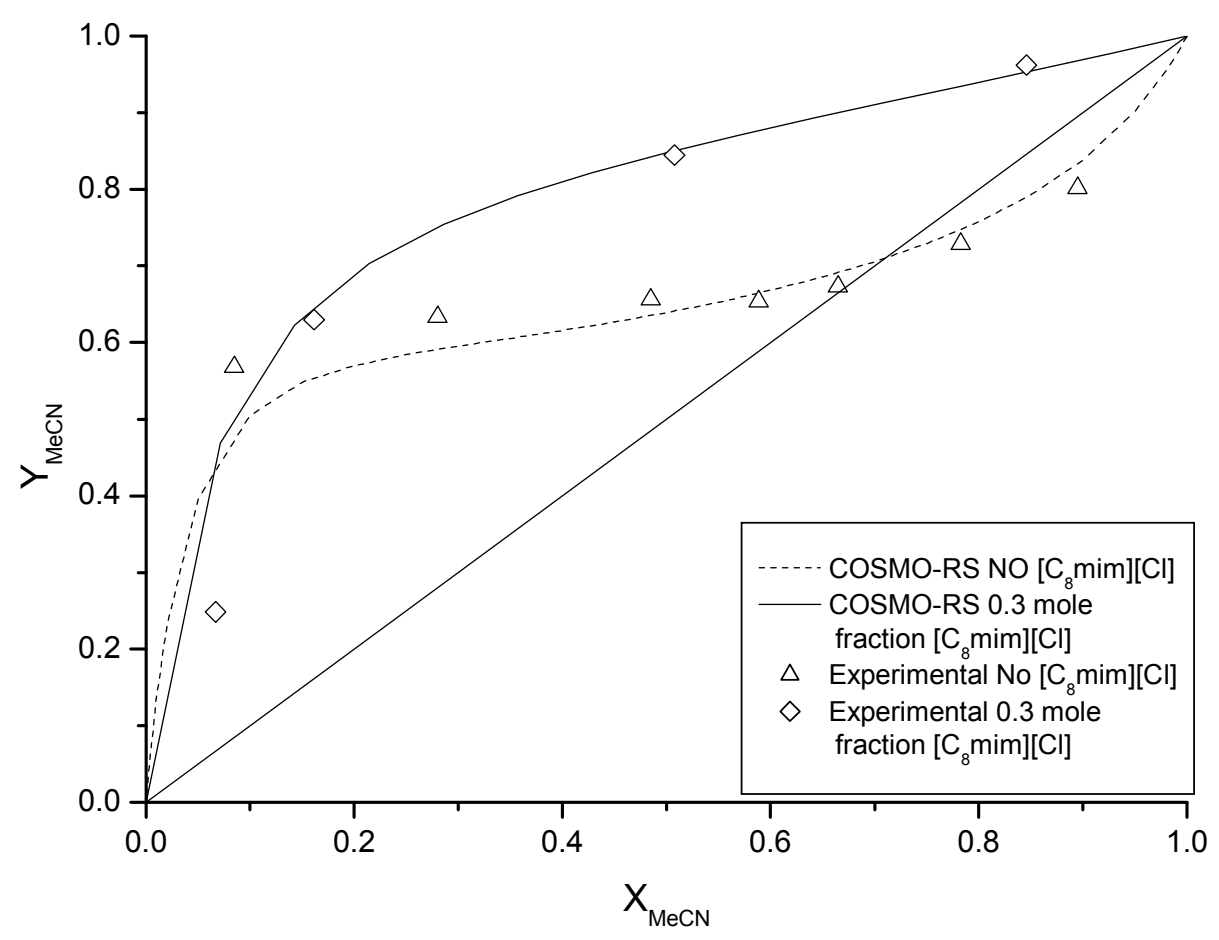


40

Figure 8

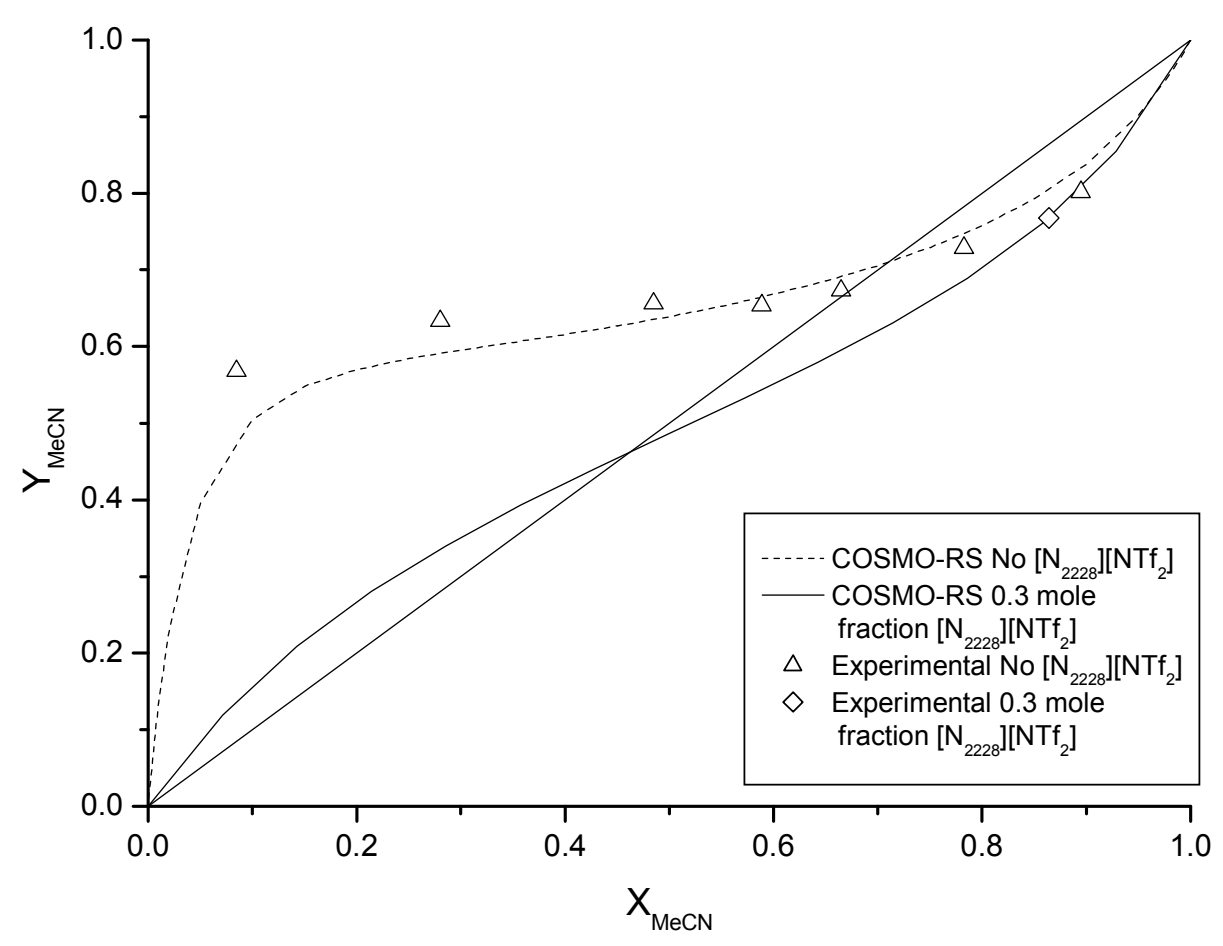



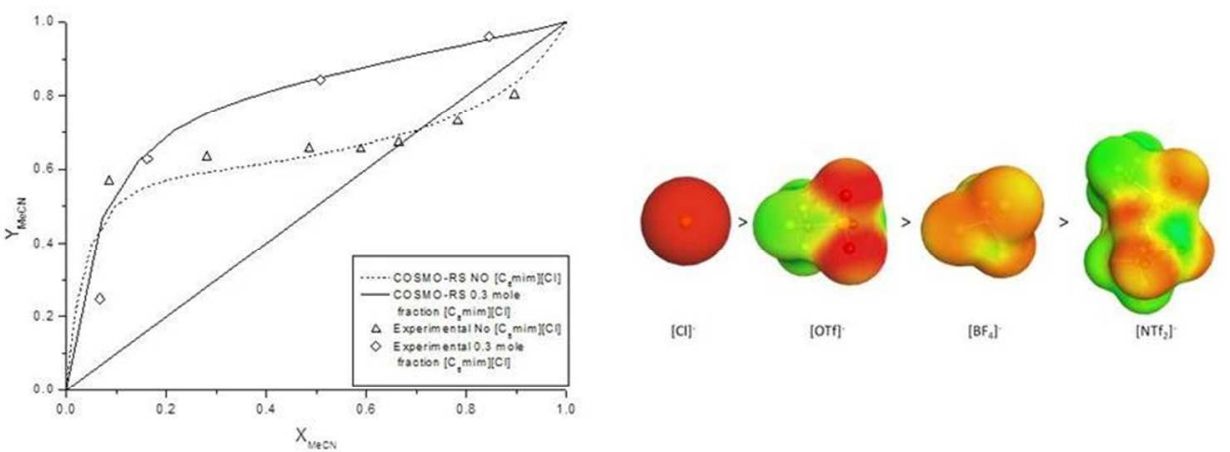

Splitting the MeCN-water azeotrope using ionic liquids: strongly anion-dependent

$166 \times 70 \mathrm{~mm}(150 \times 150 \mathrm{DPI})$ 